\title{
Synergistic interaction of ultraviolet light and zinc oxide photosensitizer for enhanced microbial inactivation in simulated wash-water
}

Duygu Ercan ${ }^{1}$, Andrea Cossu ${ }^{2}$, Nitin Nitin ${ }^{2 *}$, Rohan V. Tikekar ${ }^{1 *}$

${ }^{1}$ Department of Nutrition and Food Science, University of Maryland-College Park, MD 20742, USA.

${ }^{2}$ Department of Food Science and Technology, University of California-Davis, Davis, CA 95616, USA.

\section{*Corresponding author}

Dr. Rohan V. Tikekar

Dr. Nitin Nitin

Assistant Professor

Associate professor

Department of Nutrition and Food Science

Department of Food Science and Technology,

University of Maryland-College Park University of California-Davis,

112 Skinner Building, College Park, MD

Davis, CA 95616, USA.

20742

nnitin@ucdavis.edu; 301-405-4509

rtikekar@umd.edu, 301-405-4509

Rohan V. Tikekar and N. Nitin claim joint corresponding authorship on this paper. 


\section{ABSTRACT}

Synergistic interaction of ultraviolet light (UV-A) and zinc oxide $(\mathrm{ZnO})$ was investigated for enhanced inactivation of Escherichia coli BL21 and T7 bacteriophage in simulated washwater. In the absence of organic content, UV-A $\left(9.53 \mathrm{~J} / \mathrm{cm}^{2}\right)$ and $1 \mathrm{mM} \mathrm{ZnO}$ alone caused 3.9 and $0.7 \log \mathrm{CFU} / \mathrm{mL}$ reductions in logarithmic phase bacteria after $60 \mathrm{~min}$ respectively, while a combined treatment caused $6 \log \mathrm{CFU} / \mathrm{mL}$ reductions. Stationary-phase bacteria were more resistant and a combined treatment caused only $3.5 \log \mathrm{CFU} / \mathrm{mL}$ reductions. Organic matter in the wash-water lowered the inactivation rates. Nevertheless, approximately 2-log reductions were observed at the highest organic load. T7 bacteriophage was not sensitive to UV-A alone. However, $1 \mathrm{mM}$ photo-irradiated $\mathrm{ZnO}$ caused $6.00 \mathrm{log} \mathrm{PFU} / \mathrm{mL}$ reductions after $60 \mathrm{~min}$. Bacteriophage inactivation was also significantly lowered by organic matter. The reactive oxygen species generated from photo-irradiated $\mathrm{ZnO}$ were responsible for the microbial inactivation. UV-A irradiated $\mathrm{ZnO}$ is an attractive sanitation approach for fresh-produce washing.

\section{KEYWORDS}

Fresh produce, photodynamic inactivation, zinc oxide, ultraviolet light, cross-contamination, food safety 


\section{INTRODUCTION}

Food safety is a significant public health concern in the world. In the US alone, each year approximately 1 out of 6 person gets sick, 128,000 are hospitalized, and 3,000 die of foodborne diseases (CDC, 2011). The most common causes of foodborne illness are viral or bacterial contamination of foods (Pigott, 2008). Raw fruits and vegetables are the second leading cause of food-borne illnesses, which also costs the US economy $\$ 6.9$ billion in the loss of productivity and medical expenses per year (Luksiene \& Brovko, 2013). Decontamination of fresh-produce is typically carried out during the washing operation by incorporation of chemical sanitizing agents such as chlorine, iodophors, and quaternary ammonium compounds (Luksiene \& Brovko, 2013). However, chemical treatment is not environmentally friendly and has been associated with occupational and operational hazards. The fresh-cut produce industry commonly uses sodium hypochlorite as sanitizing agent, but by-products such as trihalometanes and chloramines formed by the interaction between the organic matter in the wash water and sodium hypochlorite are potentially harmful for humans (Ramaswamy, Ahn, Balasubramaniam, Rodriguez Saona, \& Yousef, 2013; Tirpanalan, Zunabovic, Domig, \& Kneifel, 2011; Luksiene \& Brovko, 2013). Moreover, the efficacy of chlorine decreases in the presence of organic content through binding with organic materials (Tirpanalan et al., 2011; Betts \& Everis, 2005). For example, while Handojo, Lee, Hipp, and Pascall (2009) found that 100 ppm chlorine can inactivate Escherichia coli K-12 and Staphylococcus epidermidis by $5 \log \mathrm{CFU} / \mathrm{mL}$ in the absence of organic content, another study reported only $1.2 \log \mathrm{CFU} / \mathrm{mL}$ reductions in E. coli $\mathrm{O} 157: \mathrm{H} 7$ during washing of lettuce using 200 ppm chlorine in 10 min (Kondo, Murata, \& Isshiki, 2006). Similar to the effect on bacterial inactivation, Feliciano, Li, Lee, and Pascall (2012) observed that the organic content decreased the effect of chlorine on norovirus (MNV-1) as well. Therefore, there is a need for new technologies that can effectively inactivate bacteria and viruses in wash-water. 
Photosensitized materials have been used for their antibacterial and antiviral activities in medical and environmental applications (Allison, Mang, Wilson, \& Vongtama, 1998; Banfi et al., 2006; Omar, Wilson, \& Nair, 2008; Murakami et al., 2015). Interaction of UV-A light with endogenous or exogenous photosensitizers can generate reactive oxygen species (ROS) that cause damage to cell membrane, protein, and DNA structures, resulting in cell death. Generation of ROS can also address a critical limitation of UV light alone such as low penetration depth within the medium in the presence of organic load (Ngadi, Smith, \& Cayouette, 2003). However, this approach has not been explored significantly in the food industry. The key questions related to applications of photosensitizers in food systems include: (a) the role of organic content in limiting activation of photosensitizers and the resulting microbial decay; (b) the influence of physiological state of microbes in influencing activity of photosensitizers; and (c) the ability of photosensitizers to manage bacterial and viral contaminants in food relevant environment.

$\mathrm{ZnO}$ is an inorganic metal oxide, which acts as a photosensitizer in its powder or nanoparticle form under UV-A light (Liu and Yang, 2003; Kairyte, Kadys, \& Luksiene, 2013). In addition to its photo-activity, $\mathrm{ZnO}$ particles can act as an antimicrobial compound in the dark, possibly due to binding of the particles on the bacterial surface through the electrostatic forces (L. Zhang, Jiang, Ding, Povey, \& York, 2006). ZnO particles at nano and micrometer size itself has been extensively evaluated for its antimicrobial activity (Sawai \& Yoshikawa, 2004; Jin, Sun, Su, Zhang, \& Sue, 2009; Adams, Lyon, \& Alvarez, 2006; Huang et al., 2008; Jones, Ray, Ranjit, \& Manna, 2008). ZnO particles have been found to have bactericidal property against Salmonella spp. (Jin et al., 2009), Streptococcus spp., Staphylococcus spp. (Huang et al., 2008), Escherichia coli (Zhang et al., 2006; Padmavathy \& Vijayaraghavan, 2008; Zhang et al., 2006), Candida albicans, Saccharomyces cerevisiae, Aspergillus niger, and Rhizopus stolonifer (Sawai \& Yoshikawa, 2004). Moreover, recently ZnO particles were modified by 
doping with $\mathrm{Al}$, Ta, or Ag to increase their photocatalytic and antimicrobial activities (Guo et al., 2015; Karunakaran, Rajeswari, \& Gomathisankar, 2011; P. Zhang, Hong, Chen, Feng, \& Badami, 2014). However, a simultaneous treatment of UV-A and ZnO particles to sanitize wash-water used for produce washing has not been well characterized. $\mathrm{ZnO}$ particles including nanoparticles are safe and biocompatible (Zhou, Xu, \& Wang, 2006) and FDA has listed $\mathrm{ZnO}$ powder as GRAS (Generally Recognized As Safe) (SCOGS,FDA). However, the regulatory status of the nano and micro sized $\mathrm{ZnO}$ particles is unclear.

Our aim was to investigate the UV-A irradiated $\mathrm{ZnO}$ particles based process to inactivate bacteria (Escherichia coli BL21) and viruses (T7 phage) in the presence of different organic content to simulate the wash-water used for washing of fresh-produce. To develop further insights into the mechanism of action of photo-irradiated $\mathrm{ZnO}$, membrane damage in bacteria and the generation of reactive oxygen species were also evaluated.

\section{MATERIALS AND METHODS}

\subsection{Materials}

Luria-Bertani (LB) broth and agar (LBA) were purchased from Fisher BioReagents (Pittsburgh, $\mathrm{PA}$ ). $\mathrm{NaCl}, \mathrm{ZnO}$, and phosphate buffered saline (PBS) were purchased from Sigma Aldrich (St. Louis, MO). The probes including 5-(and-6)-chloromethyl-2',7'dichlorodihydrofluorescein diacetate, acetyl ester (CM-H ${ }_{2}$ DCFDA), and Sytox-Orange were purchased from Life Technologies (Eugene, OR). Hydroxyphenyl fluorescein (HPF) probe was purchased from Cayman Chemical (Ann Arbor, MI). Escherichia coli BL21 (ATCC \#BAA-1025) and T7 phages (ATCC (\#BAA-1025-B2)) were purchased from ATCC

(Manassas, VA). Chemical oxygen Demand (COD) standard solution (1000 mg/L) and COD Digestion Vials (High Range) were obtained from Hach Company (Loveland, CO). 


\subsection{Simulated wash-water}

LB broth was used to simulate organic matter usually present in fresh produce wash-water. The concentrations of LB broth used were 200, 600, and $1000 \mathrm{mg} / \mathrm{L}$ to mimic varying organic load. The sample without organic content was prepared with $0.9 \% \mathrm{NaCl}$ to provide osmotic balance for the microorganisms. The chemical oxygen demand (COD) of this simulated washwater was measured using a US-EPA reactor digestion method (Standard Method 5220 D, USEPA, 1980). Two milliliter each of simulated wash-water samples and the COD standard solutions were digested in high range COD digestion vials at $150{ }^{\circ} \mathrm{C}$ in DRB200 Reactor (Hach Company, Loveland, CO) for $2 \mathrm{~h}$. Then, the digested samples and standards were cooled down to room temperature and the COD values were determined by a colorimetric method at $620 \mathrm{~nm}$ using a colorimeter (Hach Company, Loveland, CO). The COD values of the samples were calculated from the interpolation on the standard curve obtained from the absorbance values of the standards.

\subsection{Microbiological cultivation}

Escherichia coli BL21 was grown in $10 \mathrm{~mL}$ of $\mathrm{LB}$ broth for $3 \mathrm{~h}$ and $24 \mathrm{~h}$ at $37^{\circ} \mathrm{C}$ to obtain the bacterial population in logarithmic (absorbance of 0.4 at $600 \mathrm{~nm}$ ) and stationary phases (absorbance of 1.5 at $600 \mathrm{~nm}$ ), respectively. The culture of E. coli BL21 grown in LB broth was washed twice with $0.9 \% \mathrm{NaCl}$ to remove the adsorbed culture medium components, followed by a centrifugal separation for $2 \mathrm{~min}$ at $10000 \times g$ and $4^{\circ} \mathrm{C}$. After the washing step, the pellet was re-suspended in simulated wash-water of varying organic loads $(0-1000 \mathrm{mg} / \mathrm{L}$ LB). The initial population of E. coli BL21 was adjusted to $1 \times 10^{6} \mathrm{CFU} / \mathrm{mL}$ for both stationary and logarithmic phase cultures.

T7 phages were used as a model for non-enveloped, double-strand DNA viruses. The stock phage sample was prepared by incubating the phage and the mid-log phase culture of $E$. coli 
BL21 in LB broth in a shaking incubator at $37^{\circ} \mathrm{C}$ and $250 \mathrm{rpm}$ for $4 \mathrm{~h}$. Then, $20 \% \mathrm{v} / \mathrm{v}$ chloroform was added to lyse the remaining bacteria and the lysate was incubated at $37^{\circ} \mathrm{C}$ for 20 min with $150 \mathrm{rpm}$ shaking. The solution was centrifuged at $5652 \mathrm{~g}$ for $10 \mathrm{~min}$, the supernatant was recovered and vacuum filtered with a $0.45 \mu \mathrm{m}$ filter. Phage activity of stock phage sample was approximately $1 \times 10^{11} \mathrm{PFU} / \mathrm{mL}$.

\section{4. $\quad \mathrm{ZnO}$ and UV-A treatment}

A bench-top, batch type equipment was used for the UV-A light treatment. The apparatus consisted of four UV-A lamps (320-400 nm, 18 Watt, Actinic BL, Philips N.V.) mounted on the ceiling of a closed box (Figure 1). The predominant wavelength range emitted by the lamp was 340 to $400 \mathrm{~nm}$ with a peak at $360 \mathrm{~nm}$. Two milliliter the test sample was placed in an individual well of a 12-well plate and the entire plate was placed under the UV-A lamps enclosed within the box. The depth of the sample was $1 \mathrm{~cm}$. The distance between the lamps and the surface of the solution within the wells was $8.0 \mathrm{~cm}$. The average incident UV-A intensity measured at the location where the well-plates were kept was $2646 \pm 212 \mu \mathrm{W} / \mathrm{cm}^{2}$. Test solution consisted of $\mathrm{ZnO}(0,0.1,1,5 \mathrm{mM})$ sonicated for $1 \min (100 \mathrm{~W}, 42 \mathrm{kHz})$ to disintegrate the aggregates, mixed with the simulated wash water of varying organic load containing $10^{6} \mathrm{CFU} / \mathrm{mL}$ of bacteria or $10^{7} \mathrm{PFU} / \mathrm{mL}$ of $\mathrm{T}-7$ phage. The UV-A treatments were performed for $1 \mathrm{~h}$. Samples were taken at 0, 15, 30, 45, and $60 \mathrm{~min}$. The experiments were also performed in the dark for $60 \mathrm{~min}$ in the absence and presence of $\mathrm{ZnO}$ as controls.

\subsection{Microbiological analysis}

i) Escherichia coli BL21: The treated samples were serially diluted into the phosphate buffered saline and spread-plated in duplicate on LB agar. The plates were incubated at $37^{\circ} \mathrm{C}$ for $24 \mathrm{~h}$. The population of $E$. coli BL21 was interpreted in terms of $\log$ CFU/mL sample. 
In order to investigate whether the UV-A process caused mere injury or the complete cell death, enrichment of the UV-A treated samples was performed to resuscitate injured cells. The protocol included transferring of $1 \mathrm{~mL}$ of treated sample into $9 \mathrm{~mL}$ of $\mathrm{LB}$ broth and incubating at $37{ }^{\circ} \mathrm{C}$ for 24 to $48 \mathrm{~h}$. Then, the sample was plated on LB agar and incubated for $24 \mathrm{~h}$ at $37^{\circ} \mathrm{C}$.

ii) T7 Phage: Phage activity was quantified using the standard soft agar overlay plating assay (Han et al., 2014). Phage samples were serially diluted into phosphate buffered saline.

One hundred microliters of each sample were combined with $250 \mu \mathrm{L}$ of fresh bacterial culture with an optical density of 1.5 measured at $600 \mathrm{~nm}$. The samples were incubated for $10 \mathrm{~min}$ and then combined with $3 \mathrm{~mL}$ of molten agar $(0.75 \%$ agar $)$ at $45^{\circ} \mathrm{C}$. The molten agar mixture was poured onto a pre-warmed LB agar plate and allowed to solidify. Once the plates solidified, they were inverted and incubated at room temperature $\left(22^{\circ} \mathrm{C}\right)$ overnight. After incubation, the plaques were counted and reported as plaque forming units (PFU/mL).

\subsection{Particle size, $\zeta$-potential, and maximum absorbance peak of $\mathrm{ZnO}$}

The $\zeta$-potential and size of $\mathrm{ZnO}$ particles in $1 \mathrm{mM} \mathrm{ZnO}$ solution was measured using a particle size and $\zeta$-potential analyzer (Malvern Zetasizer, MA). The settings were material: $\mathrm{ZnO}$, dispersant: water, measurement angle: $90^{\circ}$, measurement duration: automatic. Particle refractive index for $\mathrm{ZnO}$ was 2.0034 .

The size of the $\mathrm{ZnO}$ particles was observed by transmission electron microscopy (TEM) imaging. A 400 mesh copper grid with formvar/carbon support film (Ted Pella, Inc., Redding, CA) was placed on the Parafilm square. A $10 \mu \mathrm{L}$ drop of $1 \mathrm{mM} \mathrm{ZnO}$ solution was placed onto the grid and left in a dust-free environment for $10 \mathrm{~min}$. Excess liquid was wicked off with filter paper. A $10 \mu \mathrm{L}$ drop of $1 \%$ PTA pH 5.8 (phosphotungstic acid) was added to the 
grid and wicked off immediately. Grids were allowed to air-dry completely before viewing in a Philips CM120 (FEI/Philips Inc, Hillsborough, Or.) electron microscope at 80KV.

\subsection{Absorbance of $\mathrm{ZnO}$ solutions under $\mathrm{UV}$-A wavelength}

The absorbance values of different concentrations of $\mathrm{ZnO}$ solutions $(0,0.1,1,5 \mathrm{mM})$ were measured at $360 \mathrm{~nm}$ to evaluate the effect of suspended particles to UV light penetration.

\subsection{Membrane damage}

The membrane damage occurred in E. coli BL 21 during the treatment was observed by using Sytox-Orange dye, a probe that can only permeate the disrupted or damaged cellular membrane. The SYTOX Orange stain is non-fluorescent except when bound to nucleic acids. When the membrane damage occurs, the dye can enter into the cell and bind to nucleic acids (Biggerstaff et al., 2006). Test solutions consisting of bacteria $\left(10^{6} \mathrm{CFU} / \mathrm{mL}\right)$ suspended in $0.9 \%$ sodium chloride solution without the LB were treated under UV-A in the absence and presence of $1 \mathrm{mM} \mathrm{ZnO}$. Subsequently, the treated samples were incubated with $5 \mu \mathrm{M}$ SytoxOrange for $15 \mathrm{~min}$ at room temperature in the dark (Biggerstaff et al., 2006). The fluorescent intensity was measured using a plate-reader (Spectrofluor Plus, TECAN) with excitation and emission wavelengths of $488 \mathrm{~nm}$ and $580 \mathrm{~nm}$, respectively. The control for this experiment consisted of samples containing $1 \mathrm{mM} \mathrm{ZnO}$ placed in the dark for up to $1 \mathrm{~h}$. The fluorescence intensity ratio was calculated as shown in the equation below:

$$
\text { Fluorescence intensity ratio }=\frac{\text { fluorescence intensity }_{\text {at time } t}}{\text { fluorescence intensity at time } 0}
$$

The membrane damage was also visualized by TEM imaging. Simulated wash water without the organic load containing $1 \times 10^{6} \mathrm{CFU} / \mathrm{mL}$ E. coli $\mathrm{BL} 21$ and $1 \mathrm{mM} \mathrm{ZnO}$ was exposed to UVA for $60 \mathrm{~min}$. Then, the treated sample was centrifuged for $2 \mathrm{~min}$ at 10,000 $\mathrm{g}$ and the pelleted 
cells were fixed in Karnovsky's Fixative (Polysciences, Warrington, PA). As a control, cells without $\mathrm{ZnO}$ and UV-A treatment were fixed in a similar manner. Cells were spun down in $0.5 \mathrm{~mL}$ micro-centrifuge tubes, rinsed in $100 \mathrm{mM}$ sodium phosphate buffer, and post-fixed with $1 \% \mathrm{OsO}_{4}$ in the same phosphate buffer for $2 \mathrm{~h}$. Dehydration of the cells was accomplished using ascending concentrations of acetone, ranging from $30 \%$, to $100 \%$ acetone. Dehydration steps with $95 \%$ and $100 \%$ of acetone were repeated three times. The samples were infiltrated in Embed 812 and Araldite 6005 resin (Electron Microscopy Sciences, Hatfield, PA) before final embedding and polymerization in the same microcentrifuge tubes. Ultrathin sections were cut using a Diatome diamond knife. Sections were placed onto copper grids and stained with $2 \%$ uranyl acetate in $70 \%$ ethanol for $20 \mathrm{~min}$ and counterstained with lead citrate for 2 min before viewing in a Philips CM120 electron microscope (Mollenhauer, 1964). Images were acquired using Gatan Digital Micrograph software and a Gatan MegaScan Camera (Pleasanton, CA).

\subsection{Generation of reactive oxygen species (ROS) from photosensitization of $\mathrm{ZnO}$}

CM-H2 DCFDA (5-(and-6)-chloromethyl-2',7'-dichlorodihydrofluorescein diacetate, acetyl ester) (Molecular Probes-Invitrogen, Carlsbad, CA) was used to detect miscellaneous ROS generated from UV-A induced sensitization of $\mathrm{ZnO}$. A selective fluorescent probe, hydroxyphenyl fluorescein (HPF, H36004) was used to specifically detect the hydroxyl radicals. The individual fluorescent probe was added at a level of $5 \mu \mathrm{M}$ to the simulated wash water without the organic content. Then, the samples were mixed with 0 or $1 \mathrm{mM} \mathrm{ZnO}$ and treated with UV-A for $1 \mathrm{~h}$. As a negative control, the samples were also stored in the dark for $1 \mathrm{~h}$. The fluorescence intensity for all the probes was measured with the excitation and emission peaks at 488 and $520 \mathrm{~nm}$, respectively. The fluorescence intensity ratio was calculated as shown in the equation: 


$$
\text { Fluorescence intensity ratio }=\frac{\text { fluorescence intensity }_{U V-A \text { trated }}}{\text { fluorescence intensity } \text { inon }-U V-A \text { treated }_{\text {inte }}}
$$

\subsection{Mathematical modeling of inactivation of $E$. coli BL21 and T7 phage}

The Weibull model was used to describe the inactivation by UV-A and UV-A irradiated ZnO treatments. This model includes the nonlinearity of semi-logarithmic survivor curves as well as the classical first-order approach (van Boekel, 2002).

$\log _{10} \frac{N}{N_{0}}=\frac{1}{2.303}\left(\frac{t}{\alpha}\right)^{\beta}$

Where, $\mathrm{N}$ is the number of surviving population $(\mathrm{CFU} / \mathrm{mL}$ or $\mathrm{PFU} / \mathrm{mL}), \mathrm{N}_{0}$ is initial number of population $(\mathrm{CFU} / \mathrm{mL}$ or $\mathrm{PFU} / \mathrm{mL}), \mathrm{t}$ is the treatment time $(\mathrm{min}), \alpha$ is the characteristic time (min), $\beta$ shape parameter (unitless).

Then, $\alpha$ and $\beta$ were used to calculate the reliable life, $t_{R}$, which correspond to the $D$-value for the first log reduction (van Boekel, 2002; Bialka, Demirci, \& Puri, 2008).

$t_{R}=\alpha \times(2.303)^{\beta}$

The log-linear model, which includes a first order inactivation kinetic, was also used to predict the microbial inactivation by UV-A and $\mathrm{ZnO}$ treatment.

$\log _{10} \frac{N}{N_{0}}=-k t$

Where, $\mathrm{k}$ is the first-order extinction coefficient $\left(\mathrm{min}^{-1}\right)$.

The models were constructed using the averages from the two experimental data sets, and a third data set was used to confirm the fit. The non-linear least squares regression method was used to predict $\alpha$ and $\beta$.

The goodness-of-fit for the fitted models was evaluated by root mean square error (RMSE) and mean absolute error (MAE) between the calculated data from the model and the 
experimental data. Moreover, the intercept and $\mathrm{R}^{2}$ of the linear regression line were also calculated from the model.

\subsection{Statistical analysis}

Each treatment was performed in triplicate. The significant difference between the microbial reductions by different treatments was analyzed with the analysis of variance Tukey's method at the $95 \%$ confidence interval using the MINITAB Statistical Software package (Version 17; State College, PA).

\section{RESULTS AND DISCUSSION}

\subsection{Effects of UV-A irradiated $\mathrm{ZnO}$ on the inactivation of $E$. coli $\mathrm{BL} 21$ in stationary phase}

Al doped $\mathrm{ZnO}$ particles with a $\xi$ - potential of $+0.8 \mathrm{mV}$ and a maximum peak absorbance at $334 \mathrm{~nm}$ were used in this study. The mean diameter of $1 \mathrm{mM} \mathrm{ZnO}$ particles in aqueous dispersion was $1240 \pm 190 \mathrm{~nm}$, while the mean diameter of $\mathrm{ZnO}$ particles measured using the TEM was $141 \pm 46 \mathrm{~nm}$ (Figure 2). The difference in the particles sizes as measured by the TEM and the light scattering measurement was potentially due to aggregation of the particles in aqueous solution. The inactivation of E.coli BL21 in stationary phase upon exposure to UV-A and in the presence of varying concentration of $\mathrm{ZnO}(0,0.1,1,5 \mathrm{mM})$ was tested (Figure 3). The bacterial population was reduced by $1.1 \pm 0.1 \log \mathrm{CFU} / \mathrm{mL}$ after a $60 \mathrm{~min}$ of exposure $\left(9.53 \mathrm{~J} / \mathrm{cm}^{2}\right)$ to $\mathrm{UV}-\mathrm{A}$ alone, while a sixty min incubation in the presence of $0.1,1,5$ $\mathrm{mM} \mathrm{ZnO}$ in the dark resulted in $0.1 \pm 0.0,0.6 \pm 0.1,0.7 \pm 0.2 \log \mathrm{CFU} / \mathrm{mL}$ reductions, respectively. When a $60 \mathrm{~min}$ of UV-A exposure $\left(9.53 \mathrm{~J} / \mathrm{cm}^{2}\right)$ was performed in the presence of $0.1 \mathrm{mM} \mathrm{ZnO}, 1.2 \pm 0.2 \log \mathrm{CFU} / \mathrm{mL}$ reductions were observed A statistical comparison of the $\log$ reductions suggested that presence of $0.1 \mathrm{mM} \mathrm{ZnO}$ under UV-A did not have a significant effect on the extent of microbial inactivation ( $p>0.05)$ compared to UV-A alone. 
However, when the $\mathrm{ZnO}$ concentration was increased to $1 \mathrm{mM}$, the reduction in the population of $E$. coli BL21 significantly increased to a $3.5 \pm 0.2 \log \mathrm{CFU} / \mathrm{mL}$ after $60 \mathrm{~min}$ of UV-A exposure $\left(9.53 \mathrm{~J} / \mathrm{cm}^{2}\right)(\mathrm{p}<0.05)$. A further increase in the concentration of $\mathrm{ZnO}$ to 5 $\mathrm{mM}$ resulted in a $4.5 \pm 0.4 \log \mathrm{CFU} / \mathrm{mL}$ inactivation of microbes after $60 \mathrm{~min}$ of exposure $\left(9.53 \mathrm{~J} / \mathrm{cm}^{2}\right)$. The microbial inactivation by UV-A in the presence of various concentrations of $\mathrm{ZnO}$ was described with the Weibull and log-linear models (Table 1). A higher $\mathrm{R}^{2}$ and lower RMSE and MAE were observed for the Weibull models compared to the log-linear models, indicating that the Weibull models described the microbial inactivation better than the loglinear models. In addition, the Weibull model was able to include the concavity within the data. The reliable life $\left(t_{R}\right)$ value, that represents the amount of time required for the first log reduction was calculated from the Weibull model constants, $\alpha$ (characteristic time), and $\beta$ (shape parameter) (van Boekel, 2002). Increasing the $\mathrm{ZnO}$ concentration to $0.1 \mathrm{mM}$ marginally lowered the $t_{R}$ compared to UV-A treatment itself (Table 1). A further increase in the $\mathrm{ZnO}$ concentration to $1 \mathrm{mM}$ substantially reduced the $t_{\mathrm{R}}$. The ratio between the $t_{R}$ values indicated an approximately 5-fold faster inactivation with $1 \mathrm{mM} \mathrm{ZnO}$ compared to $0.1 \mathrm{mM}$ $\mathrm{ZnO}$. However, it was interesting to observe that a 5-fold increase in $\mathrm{ZnO}$ concentration (between 1 and $5 \mathrm{mM} \mathrm{ZnO}$ ) resulted in only 1.6 fold increase in the rate of inactivation of the bacteria. The possible reasons behind this may include, (a) $\mathrm{ZnO}$ particles may aggregate to a larger extent at a higher concentration, thus lowering their photocatalytic activity. Since the antimicrobial activity of $\mathrm{ZnO}$ is largely dependent on its surface area (Dutta, 2011; Hotze, Badireddy, Chellam \& Wiesner 2009), aggregation of $\mathrm{ZnO}$ particles would lower its activity; and (b) the increased turbidity of $5 \mathrm{mM} \mathrm{ZnO}$ possibly lowered the penetration of UV-A light resulting in a less efficient photo-catalytic activity of $\mathrm{ZnO}$. This hypothesis is based on the absorbance values of $0,0.1,1,5 \mathrm{mM} \mathrm{ZnO}$ solution at $360 \mathrm{~nm}$. These values were $0.1 \pm 0.0$, $0.1 \pm 0.0,0.2 \pm 0.00$ and $0.6 \pm 0.01$, respectively for $0,0.1,1,5 \mathrm{mM} \mathrm{ZnO}$ solution respectively. 
Based on these results, $1 \mathrm{mM}$ was chosen as an effective concentration of $\mathrm{ZnO}$. These results showed that UV-A and $\mathrm{ZnO}$ had limited efficacy in reducing the microbial load individually, however, exposure of $\mathrm{ZnO}$ to UV-A significantly increased the rate of microbial inactivation indicating a synergistic interaction between UV-A and $\mathrm{ZnO}$. The tested concentration of nanoparticles was close to the concentration of other antimicrobial nanoparticles used in previous studies. For example, while Lipovsky, Gedanken, Nitzan, and Lubart (2011) used $1.2 \mathrm{mM}$ of $\mathrm{TiO}_{2}$ nanoparticles $(50 \mathrm{~nm})$ in combination with irradiation using $415 \mathrm{~nm}(100$ $\mathrm{mW} / \mathrm{cm}^{2}, 5 \mathrm{~min}$ ) to achieve $80-90 \%$ reduction in Staphylococcus viability, Maiti, Krishnan, Barman, Ghosh, and Laha (2014) found that the minimal inhibition concentration of silver nanoparticles $(10-40 \mathrm{~nm})$ needs to be $0.46 \mathrm{mM}$ for $E$. coli inactivation.

UV-A irradiated $\mathrm{ZnO}$ has been evaluated for the microbial inactivation in samples without organic content (Liu and Yang, 2003; Kairyte, Kadys, \& Luksiene, 2013). Liu and Yang (2003) observed an $8 \log$ CFU/mL reductions in the population of E. coli (CCRC 10675) after a $40 \mathrm{~min}$ exposure to UV-A $\left(9600 \mu \mathrm{W} / \mathrm{cm}\right.$ for $\left.40 \mathrm{~min}, 23.04 \mathrm{~J} / \mathrm{cm}^{2}\right)$ in the presence of $2 \mathrm{~g} / \mathrm{L}$ $\mathrm{ZnO}$ powder. Kairyte et al. (2013) reported that photo-activated $\left(400 \mathrm{~nm}, 2000 \mu \mathrm{W} / \mathrm{cm}^{2}\right) 1$ $\mathrm{mM} \mathrm{ZnO}$ nanoparticles caused a $7 \log \mathrm{CFU} / \mathrm{mL}$ reductions in the population of $E$. coli O157:H7, Listeria monocytogenes $\mathrm{ATC}_{\mathrm{L} 3} \mathrm{C} 7644$ after $60 \mathrm{~min}$ of exposure $\left(7.2 \mathrm{~J} / \mathrm{cm}^{2}\right)$. A direct comparison of our results with the results of these previous studies is not possible because the efficacy of inactivation by UV-A irradiated $\mathrm{ZnO}$ can vary due to the type of strain and the physicochemical properties of $\mathrm{ZnO}$ particles. The $\mathrm{t}$ morphology and the size pf $\mathrm{ZnO}$ nanoparticles is strongly dependent on the synthesis process (Li \& Haneda, 2003). Although some studies reported that the photocatalytic activity of $\mathrm{ZnO}$ particles is dependent on their morphology (Xie, Li, Zhao, Bian, \& Wei, 2011; Li \& Haneda, 2003), Raghupathi, Koodali, \& Manna (2011) observed that the antimicrobial activity of $\mathrm{ZnO}$ nanoparticles in the dark was dependent on the size of the particles. They suggested that the effect of the size can be related 
to the accumulation of $\mathrm{ZnO}$ particles in the cytoplasm of the cells. In contrast to the study of Raghupathi et al. ( 2011), Heinlaan, Ivask, Blinova, Dubourguier, \& Kahru ( 2008) found that the toxicity of $\mathrm{ZnO}$ was not dependent on the size of the particles and they stated that the intimate contact between the cell and the particles plays a major role in inactivation rather than the internalization of the particles. Nevertheless, it is evident in our study that a large fraction of zinc oxide nanoparticles aggregated to form micron sized particles that may not permeate into the bacterial cell but either attach to the cell membrane or exert their activity from the extracellular environment. Moreover, different UV wavelength and intensity can cause different effects on microorganisms due to their UV intensity dependent defense mechanism (Hoerter et al., 2005). The re-usability of $\mathrm{ZnO}$ as a photosensitizer was evaluated and it was found that $\mathrm{ZnO}$ was photoactive and was able to inactivate microorganisms with the same efficacy after two 1-hr cycles of UV-A exposure (Supplementary information section).

\subsection{Enhanced microbial inactivation by UV-A irradiated ZnO: Effect of physiological state of bacteria}

Figure 4 shows the inactivation of E.coli BL21 in the logarithmic and stationary phases upon exposure of $1 \mathrm{mM} \mathrm{ZnO}$ to $\mathrm{UV}$-A light. $1 \mathrm{mM} \mathrm{ZnO}$ caused a $6 \log \mathrm{CFU} / \mathrm{mL}$ reductions in the logarithmic phase E. coli BL21 after $60 \mathrm{~min}$ of UV-A exposure $\left(9.53 \mathrm{~J} / \mathrm{cm}^{2}\right)$, while UV-A alone and $\mathrm{ZnO}$ alone caused 3.9 \pm 0.2 and $0.7 \pm 0.1 \log \mathrm{CFU} / \mathrm{mL}$ reductions respectively in 60 min. Enrichment of the UV-A/ZnO treated bacterial suspension did not result in the microbial growth, indicating that cells were not only injured but killed. In the case of stationary phase bacteria, UV-A $\left(9.53 \mathrm{~J} / \mathrm{cm}^{2}\right)$ and $1 \mathrm{mM} \mathrm{ZnO}$ alone caused a $1.1 \pm 0.1$ and a $0.6 \pm 0.1 \mathrm{log}$ $\mathrm{CFU} / \mathrm{mL}$ reduction respectively, while a combined treatment resulted in a $3.5 \pm 0.20 \mathrm{log}$ $\mathrm{CFU} / \mathrm{mL}$ reduction after $60 \mathrm{~min}(\mathrm{p}<0.05)$. Thus, E. coli BL21 in the stationary phase was 
more resistant to both UV-A and photo-irradiated ZnO than E. coli BL21 in the logarithmic phase $(\mathrm{p}<0.05)$.

Based on the $t_{R}$ values, it is evident that compared to UV-A alone, the presence of $1 \mathrm{mM} \mathrm{ZnO}$ increased the microbial inactivation rate by approximately 4-fold when the cells were in the stationary phase, and approximately 2-fold when the cells were in the logarithmic cells (Table 2). However, this was mainly due to a higher resistance of the stationary phase bacteria to inactivation by UV-A alone compared to the logarithmic phase bacteria. This difference in the inactivation can be attributed to the differences in the defense mechanisms of microbes in the logarithmic or stationary phase against oxidative stress. These differences may include differences in the outer membrane structure, cell envelope structure as well as the activity of intracellular enzymes ( Dantur \& Pizarro, 2004; Miki and Hardt, 2013) andenzymes that limit the oxidative damage such as iron and manganese superoxide dismutase, hydroperoxidases, and glutathione reductase (Dubrac \& Touati, 2000; Tardat \& Touati, 1991). Tyrrell, Moss, and Davies (1972) explained the difference between the resistance of logarithmic and stationary phase bacteria against UV-A- vis irradiation induced inactivation (320-450 nm) based on the differences in the amount of intracellular repair enzymes. The concentration of these enzymes was higher in the stationary phase bacteria.

\subsection{Mechanism of action by UV-A irradiated ZnO}

\subsubsection{Bacterial membrane damage}

The antimicrobial mechanism of $\mathrm{ZnO}$ microparticles and nanoparticles without UV-A photoirradiation has been evaluated previously. Brayner et al. (2006) observed membrane disorganization of Gram negative bacteria after an overnight incubation of the cells with 1 $\mathrm{mM} \mathrm{ZnO}$ nanoparticles ( 8 to $14 \mathrm{~nm}$ diameter) by TEM imaging. They also stated that cellular internalization of these nanoparticles occurred within the bacteria. Similarly, Huang et al. 
(2008) reported membrane disorganization for both Gram negative and Gram positive bacteria after overnight incubation of cells with $10 \mathrm{mM} \mathrm{ZnO}$ nanoparticles of $100 \mathrm{~nm}$ diameter. Leung et al. (2012) showed that bigger ZnO particles (339-677 nm aggregation size) also caused membrane damage on Gram negative bacteria under ambient illumination.

In this study, the membrane damage was evaluated using a high affinity nucleic acid stain SYTOX Orange (Figure 5). This stain cannot permeate the living cells but easily penetrates the cells with a compromised plasma membrane (Biggerstaff et al., 2006). Upon binding the nucleic acid, the dye transforms into its fluorescent form. The dye also may bind to nucleic acids released from the cells due to membrane damage. Thus, membrane damage was evaluated based on the changes in the fluorescence intensity of the samples. UV-A and $\mathrm{ZnO}$ alone did not cause any change in fluorescence indicating that neither of the treatments alone caused a significant damage to the cell membrane. However, when compared to these controls, the fluorescence within the suspension of the bacteria in the stationary phase increased $1.3 \pm 0.1$ fold upon $60 \mathrm{~min}$ of exposure to UV-A light $\left(9.53 \mathrm{~J} / \mathrm{cm}^{2}\right)$ in the presence of $1 \mathrm{mM} \mathrm{ZnO}$. Similarly, the fluorescence increased 2.8 \pm 0.1 fold in logarithmic phase bacteria after $60 \mathrm{~min}$ of UV-A exposure $\left(9.53 \mathrm{~J} / \mathrm{cm}^{2}\right)$ in presence of $1 \mathrm{mM} \mathrm{ZnO}$. A significantly $(\mathrm{p}<0.05)$ higher fluorescence in these solutions suggest that simultaneous exposure of the bacteria to $\mathrm{ZnO}$ and $\mathrm{UV}$-A resulted in a significant damage to the bacterial cell membrane. It is also evident that the membrane damage was significantly higher in the cells in the logarithmic phase than those in the stationary phase after $1 \mathrm{~h}$ of UV-A treatment $\left(9.53 \mathrm{~J} / \mathrm{cm}^{2}\right)$ with $1 \mathrm{mM} \mathrm{ZnO}(\mathrm{p}<0.05)$. These results are consistent with the results obtained from the inactivation kinetics for the two phases (section 3.2). Figure 6 shows the TEM images of the bacteria before and after treatment. The cells treated with UV-A/ZnO treatment showed a more irregular and compact cell membrane compared to the control. Leaked out intracellular content was observed. In addition, the contrast in the cell membrane compared to intracellular 
content was significantly higher after the treatment. These morphological differences in the cell after the treatment further validate the membrane damage and the leakage of the intracellular content experienced by the bacteria.

\subsubsection{Generation of reactive oxygen species}

In the presence of light, $\mathrm{ZnO}$ can produce ROS such as hydroxyl radicals, superoxide anion and singlet oxygen, that can cause oxidative damage, denaturation of enzymes, oxidation of lipids and fragmentation of DNA (He, Zhao, Jia, Yin, \& Zheng, 2014). While Sawai and Yoshikawa (2004) reported that hydrogen peroxide generation was the primary antimicrobial mechanism of $\mathrm{ZnO}$, He et al. (2014) evaluated the reactive oxygen species produced by $\mathrm{ZnO}$ under $\mathrm{Hg}$ lamp at $365 \mathrm{~nm}$ and demonstrated the generation of multiple ROS including hydroxyl radicals, superoxide and singlet oxygen. They also stated that the type of reactive oxygen species generated depends on the shape of micro-nano structured $\mathrm{ZnO}$ in an aqueous solution. Moreover, Chandran, Netha, Ravindran, and Sudheer Khan (2014) reported the attenuation in the generation of the hydroxyl radicals by $\mathrm{ZnO}$ nanoparticles in the presence of exopolysaccharides under visible light.

In this study, generation of reactive oxygen species was evaluated by various probes (Figure 7). $\mathrm{CM}-\mathrm{H}_{2} \mathrm{DCFDA}$ was used as a generic probe to measure ROS including superoxide, hydrogen peroxide, and hydroxyl radicals (Figure 7a). The production of these ROS in the presence of $\mathrm{ZnO}$ was significantly higher than that by UV-A alone $(\mathrm{p}<0.05)$. Compared to $\mathrm{UV}-\mathrm{A}$ alone, the presence of $1 \mathrm{mM} \mathrm{ZnO}$ increased the fluorescence intensity generated from the interaction of CM- $\mathrm{H}_{2}$ DCFDA with ROS by $26.9 \pm 5.1$ fold after $15 \mathrm{~min}$ of UV-A exposure $\left(2.38 \mathrm{~J} / \mathrm{cm}^{2}\right)$. While superoxide is not very reactive against $E$. coli, when it is protonated, hydrogen peroxide or highly reactive hydroxyl radicals can be produced (Costa, Faustino, Neves, Cunha, \& Almeida, 2012). Therefore, HPF (2-[6-(4'-Hydroxy)phenoxy-3H-xanthen-3on-9-yl]benzoic acid) was also used as a probe to selectively detect highly reactive oxygen 
species (hROS) such as hydroxyl radical (Figure 7b) (Setsukinai, Urano, Kakinuma, Majima, \& Nagano, 2003). Based on the fluorescence intensity measurement, it is evident that hydroxyl radical production was not significant with UV-A alone ( $\mathrm{p} \geq 0.05$ ). However, $60 \mathrm{~min}$ of UV-A exposure $\left(9.53 \mathrm{~J} / \mathrm{cm}^{2}\right)$ in the presence of $1 \mathrm{mM} \mathrm{ZnO}$ increased the fluorescence intensity by $60.1 \pm 6.1$ fold indicating that hydroxyl radicals were generated from the UV-A irradiated $\mathrm{ZnO}$.

\subsection{Effect of the organic load on the efficacy of UV-A irradiated ZnO}

Simulated wash water containing various amounts of organic load was prepared by adding LB broth to water. LB broth has been used to mimic the organic content in wash water (Le et al., 2015). The COD value was measured using the US-EPA reactor digestion method. The concentration of LB was directly related to the $\mathrm{mg} \mathrm{O}_{2} / \mathrm{L}$ COD. The samples containing 200, 600, $1000 \mathrm{ppm}$ of LB broth had a COD of $212.3 \pm 4.7,555 \pm 1.7$ and $940.7 \pm 1.5 \mathrm{mg} \mathrm{O} / \mathrm{L}$, respectively. Figure 8 shows the effect of organic load in wash water on the efficacy of inactivation of E.coli BL21 in the stationary and logarithmic phases by treatment with $1 \mathrm{mM}$ photo-irradiated $\mathrm{ZnO}$. One millimolar $\mathrm{ZnO}$ itself in the dark caused less than $0.5 \log$ reduction at all organic contents. UV-A alone $\left(9.53 \mathrm{~J} / \mathrm{cm}^{2}\right)$ caused $1.8 \pm 0.1,0.3 \pm 0.1,0.3 \pm 0.1$ $\log \mathrm{CFU} / \mathrm{mL}$ reductions in 1 hour in the logarithmic phase bacteria, while it caused $0.6 \pm 0.1$, $0.2 \pm 0.1,0.2 \pm 0.1 \log \mathrm{CFU} / \mathrm{mL}$ reductions in in the stationary phase bacteria at $212,555,940$ $\mathrm{mg} / \mathrm{L}$ COD of organic content, respectively. Thus, the presence of organic content significantly decreased the effect of the UV-A light on the bacteria $(\mathrm{p}<0.05)$. In the presence of $1 \mathrm{mM} \mathrm{ZnO}$ and 212, 555, $940 \mathrm{mg} / \mathrm{L}$ COD of organic content, the reduction in the population of $E$. coli BL21 in logarithmic phase was $4.5 \pm 0.3,4.0 \pm 0.3,3.9 \pm 0.3 \log$ $\mathrm{CFU} / \mathrm{mL}$ respectively after 1 hour of UV-A exposure $\left(9.53 \mathrm{~J} / \mathrm{cm}^{2}\right)$. On the other hand, the population of E. coli BL21 in the stationary phase after 1 hour of UV-A exposure $\left(9.53 \mathrm{~J} / \mathrm{cm}^{2}\right)$ 
with $1 \mathrm{mM} \mathrm{ZnO}$ decreased by $2.2 \pm 0.1,2.0 \pm 0.1,1.9 \pm 0.1 \log \mathrm{CFU} / \mathrm{mL}$ in the presence of 212 , $555,940 \mathrm{mg} \mathrm{O}_{2} / \mathrm{L} \mathrm{COD}$ of organic content respectively. There was no significant difference in the population reduction of $E$. coli BL21 as the organic content was increased from 212 to $940 \mathrm{mg} / \mathrm{L}$ COD ( $\geq 00.05$ ). Thus, $1 \mathrm{mM}$ photo-irradiated $\mathrm{ZnO}$ caused a significantly higher inactivation of the bacteria in the logarithmic and stationary phases compared to the treatment with UV-A alone $(p<0.05)$, albeit the effect was attenuated by the presence of organic load. The reason might be quenching of ROS by organic content. Orlandi et al. (2012) also observed a decrease in the inactivation by photo-irradiated cationic tetraaryl-porphyrin in the presence of organic content and attributed the effect to the ability of organic content to act as an ROS scavenger and block the adsorption of the photosensitizer to the cell wall.

Table 2 shows the constants for models for the cases related to effect of organic content. The $\alpha$ values increased following the organic content increment. The $t_{R}$ values for the stationary phase bacteria decreased by $2.7,3.20$, and 3.3 fold as the organic content increased from 0 to 212, 555, and $940 \mathrm{mg} / \mathrm{L} \mathrm{COD,} \mathrm{respectively,} \mathrm{indicating} \mathrm{that} \mathrm{an} \mathrm{increase} \mathrm{in} \mathrm{the} \mathrm{organic} \mathrm{content}$ lowered the rate of inactivation. Similar trends were also observed for logarithmic phase bacteria. The inactivation rate decreased by approximately 2, 5.4, and 6 fold for the bacteria in the logarithmic phase at 212,555, $940 \mathrm{mg} / \mathrm{L} \mathrm{COD}$ of organic content respectively compared to the inactivation rate without organic content. Moreover, as the organic content increased to 555, $940 \mathrm{mg} / \mathrm{L} \mathrm{COD,} \mathrm{the} \beta$ value, which is related to concavity in the models, increased for the bacteria in both stationary and the logarithmic phases. Van Boekel (2002) associates the concavity in the curves to an adaptation of the microorganisms to the treatment. In this study, the concavity can be related to the interaction of organic material with the oxidative species generated in the system. Due to a significantly higher load of organic matter compared to the microorganisms, there was a higher probability for a redox interaction between the organic matter and the oxidizing species generated from photo-irradiation of $\mathrm{ZnO}$. The preferential 
interaction of organic matter with oxidizing species would significantly reduce the rate of microbial inactivation. For example, LB broth includes amino acids that can act as reducing agents and quench the oxidizing species (Berlett \& Stadtman, 1997).

Log-linear method was also able to describe some cases well. However, when there was a concavity in the data, the Weibull model described the case better. While the log-linear model under-predicted data in the absence of organic content, it over-predicted the inactivation in the presence of organic content in the beginning of the treatment. In addition, log-linear model had higher RMSE and MAE. All the Weibull models had $\mathrm{R}^{2}$ greater than 0.96 . Moreover, the intercept and the slope of the regression line were close to 1 and 0 and both, RMSE and MAE values were close to 0 for the Weibull models indicating a good agreement between the data and the model.

\subsection{Enhanced inactivation of $T$-7 bacteriophage by $\mathrm{UV}$-A irradiated $\mathrm{ZnO}$}

T7 bacteriophage was not sensitive to UV-A alone (Figure 9). However, when the UV-A exposure $\left(9.53 \mathrm{~J} / \mathrm{cm}^{2}\right)$ was performed in the presence of $1 \mathrm{mM} \mathrm{ZnO}$, the population of $T 7$ bacteriophage reduced by $6.0 \pm 0.4 \log \mathrm{PFU} / \mathrm{mL}$ in $1 \mathrm{~h} . T 7$ is a non-enveloped dsDNA virus and has a single proteinaceous capsid (Hotze, 2009). It has been shown that enveloped viruses are significantly more sensitive to photodynamic destruction than non- enveloped viruses (Costa, Faustino, et al., 2012; Hotze, 2009). Costa, Tomé, et al. (2012) also evaluated the inactivation of phages by white light irradiated tricationic porphyrin Tri-Py+-Me-PF and reported that RNA phages were more sensitive than DNA phages. Therefore, $T 7$ phage is an appropriate phage or viral model to test the reduction in viral load with the UV-A irradiated $\mathrm{ZnO}$ particles.

A treatment with $1 \mathrm{mM}$ UV-A irradiated $\mathrm{ZnO}$ was significantly affected by the addition of $212,555,940 \mathrm{mg} \mathrm{O}_{2} / 1 \mathrm{COD}$ of organic content $(\mathrm{p}<0.05)$. The reduction in the population of 
$T 7$ bacteriophage in the presence of $1 \mathrm{mM} \mathrm{ZnO}$ after 1 hour UV-A $\left(9.53 \mathrm{~J} / \mathrm{cm}^{2}\right)$ treatment was $1.9 \pm 0.6,1.7 \pm 0.1$, and $0.6 \pm 0.2 \log \mathrm{PFU} / \mathrm{mL}$ at $212,555,940 \mathrm{mg} / \mathrm{L} \mathrm{COD}$ of organic content, respectively. Similarly, Snow, Park, and Kim (2014) reported four times less MS2 phage inactivation rate in the presence of $5 \mathrm{mg} / \mathrm{l}$ organic content.

Table 3 shows the constants for the Weibull models of $T 7$ phage inactivation at different organic content in the presence of $1 \mathrm{mM} \mathrm{ZnO}$. Based on the $\mathrm{t}_{\mathrm{R}}$ values, the inactivation of $\mathrm{T} 7$ phage by UV-A irradiated $\mathrm{ZnO}$ decreased by $34.7,41$, and 79.2 fold as the organic content increased from 0 to $212,555,940 \mathrm{mg} / \mathrm{L}$ COD respectively. A decrease in the inactivation rate of viral particles in the presence of organic content can be related to the quenching of the ROS by the organic content. The inactivation values from the models were compared with the experimental values and the $\mathrm{R}^{2}$, MAE, and RMSE proved that the Weibull models described the T7 phage inactivation well (Table 3). The inactivation of $T 7$ phage was also described with the log-linear model. However, this model couldn't predict the inactivation in the beginning of treatment without organic content. Moreover, as the organic content reached 600 ppm, the log-linear model over-predicted the $T 7$ phage reduction in the beginning of the treatment. The variation in the prediction caused increased in the RMSE and MAE values. Similar to our study, Hotze et al. (2009) evaluated the effect of UV-A irradiated fullerol against $\mathrm{T} 7$ phage. They reported that $\mathrm{T} 7$ were not susceptible to UVA alone. They also suggested that singlet oxygen produced by fullerol near the phages caused inactivation of the phages. Costa, Tomé, et al. (2012) stated that $T 7$ phage inactivation by photo-irradiated mesotetrakis (4 - $\beta$ - D -glucosylphenyl)porphyrin and 5,10,15- (4 - $\beta$ - D- galactosylphenyl)- 20(pentafluorophenyl)porphyrin was mainly due to production of ROS rather than the singlet oxygen production because they observed a stronger inhibition of the inactivation process when they used free radical scavenger (DMTU) compared to when they used the singlet oxygen scavenger (sodium azide). In this study, since the production of reactive oxygen 
species increased significantly with the addition of $\mathrm{ZnO}$, ROS probably played a significant role in the inactivation of $\mathrm{T} 7$ phages.

\section{CONCLUSION}

UV-A irradiated ZnO improved the inactivation of E. coli BL21 and T7 phages. The UV-A exposure of $\mathrm{ZnO}$ resulted in a generation of diverse reactive oxygen species that may have damaged the cell membrane of the bacteria, resulting in cell death. The rate of inactivation was affected by the growth phase of the bacteria, with stationary phase being more resistant to the inactivation. The presence of organic load significantly reduced the efficacy of bacterial and viral inactivation, possibly due to competitive quenching of the oxidizing species generated by photo-irradiated $\mathrm{ZnO}$ particles. This study highlights that photo-irradiated $\mathrm{ZnO}$ particles can be used as an alternative method to the chemical treatments for microbial inactivation in wash water. This material is particularly attractive for food applications due to its GRAS status in the US. However, to enable commercialization of this approach, further research is necessary to detect whether harmful by-products are formed as a result of this treatment and understand the environmental fate and impact of $\mathrm{ZnO}$ nano and micro particles.

\section{ACKNOWLEDGEMENTS}

This project was supported by Agriculture and Food Research Initiative grant no. 201467017-21642 from the USDA National Institite of Food and Agriculture (USDA-NIFA) Program in Improving Food Quality (A1361) and grant no. 2015-68003-23411 from USDANIFA Program Enhancing Food Safety through Improved Processing Technologies (A4131). We thank Electron Microscopy laboratory at the Department of Pathology and Laboratory Medicine in University of California Davis. 


\section{REFERENCES}

Adams, L. K., Lyon, D. Y., \& Alvarez, P. J. J. (2006). Comparative eco-toxicity of nanoscale $\mathrm{TiO} 2, \mathrm{SiO} 2$, and $\mathrm{ZnO}$ water suspensions. Water Research, 40(19), 3527-3532. doi:10.1016/j.watres.2006.08.004

Allison, R. R., Mang, T. S., Wilson, B. D., \& Vongtama, V. (1998). Tin ethyl etiopurpurininduced photodynamic therapy for the treatment of human immunodeficiency virusassociated kaposi's sarcoma. Current Therapeutic Research, 59(1), 23-27. doi:10.1016/S0011-393X(98)85020-0

Banfi, S., Caruso, E., Buccafurni, L., Battini, V., Zazzaron, S., Barbieri, P., \& Orlandi, V. (2006). Antibacterial activity of tetraaryl-porphyrin photosensitizers: an in vitro study on Gram negative and Gram positive bacteria. Journal of Photochemistry and Photobiology. B, Biology, 85(1), 28-38. doi:10.1016/j.jphotobiol.2006.04.003

Berlett, B. S., \& Stadtman, E. R. (1997). Protein oxidation in aging, disease, and oxidative stress. The Journal of Biological Chemistry, 272(33), 20313-6.

Betts, G., \& Everis, L. (2005). Alternatives to hypochlorite washing systems for the decontamination of fresh fruit and Vegetables. In Jongen, W (Ed) Improving the Safety of Fresh Fruit and Vegetables (pp. 351-372). Woodhead Publishing Inc. doi:10.1533/9781845690243.3.351

Bialka, K. L., Demirci, A., \& Puri, V. M. (2008). Modeling the inactivation of Escherichia coli O157:H7 and Salmonella enterica on raspberries and strawberries resulting from exposure to ozone or pulsed UV-light. Journal of Food Engineering, 85(3), 444-449. doi:10.1016/j.jfoodeng.2007.08.007

Biggerstaff, J. P., Le Puil, M., Weidow, B. L., Prater, J., Glass, K., Radosevich, M., \& White, D. C. (2006). New methodology for viability testing in environmental samples. Molecular and Cellular Probes, 20(2), 141-6. doi:10.1016/j.mcp.2005.11.006

Brayner, R., Ferrari-Iliou, R., Brivois, N., Djediat, S., Benedetti, M. F., \& Fiévet, F. (2006). Toxicological impact studies based on Escherichia coli bacteria in ultrafine $\mathrm{ZnO}$ nanoparticles colloidal medium. Nano Letters, 6(4), 866-70. doi:10.1021/nl052326h

CDC. (2011). CDC - 2011 Estimates of Foodborne Illness. Retrieved from http://www.cdc.gov/foodborneburden/2011-foodborne-estimates.html. Accessed October $13,2015$.

Chandran, P., Netha, S., Ravindran, A., \& Sudheer Khan, S. (2014). Effect of exopolysaccharides on photocatalytic activity of $\mathrm{ZnO}$ nanoparticles. Colloids and Surfaces. B, Biointerfaces, 122, 611-616. doi:10.1016/j.colsurfb.2014.07.039

Costa, L., Faustino, M. A. F., Neves, M. G. P. M. S., Cunha, A., \& Almeida, A. (2012). Photodynamic inactivation of mammalian viruses and bacteriophages. Viruses, 4(7), 1034-1074. doi:10.3390/v4071034 
Costa, L., Tomé, J. P. C., Neves, M. G. P. M. S., Tomé, A. C., Cavaleiro, J. a S., Cunha, A., ... Almeida, A. (2012). Susceptibility of non-enveloped DNA- and RNA-type viruses to photodynamic inactivation. Photochemical \& Photobiological Sciences, 11(10), 15201523. doi:10.1039/c2pp25156f

Dantur, K. I., \& Pizarro, R. a. (2004). Effect of growth phase on the Escherichia coli response to ultraviolet-A radiation: influence of conditioned media, hydrogen peroxide and acetate. Journal of Photochemistry and Photobiology. B, Biology, 75(1-2), 33-39. doi:10.1016/j.jphotobiol.2004.04.006

Dubrac, S., \& Touati, D. (2000). Fur positive regulation of iron superoxide dismutase in Escherichia coli: functional analysis of the sodB promoter. Journal of Bacteriology, 182(13), 3802-3808.

Dutta, R. K. (2011). Assessing the conformational and cellular changes of $\mathrm{ZnO}$ nanoparticles impregnated Escherichia coli cells through molecular fingerprinting. Advanced Materials Letters, 2(4), 268-275. doi:10.5185/amlett.indias.195

Feliciano, L., Li, J., Lee, J., \& Pascall, M. a. (2012). Efficacies of sodium hypochlorite and quaternary ammonium sanitizers for reduction of norovirus and selected bacteria during ware-washing operations. PloS One, 7(12), e50273. doi:10.1371/journal.pone.0050273

Guo, B.-L., Han, P., Guo, L.-C., Cao, Y.-Q., Li, A.-D., Kong, J.-Z., Wu, D. (2015). The Antibacterial Activity of Ta-doped ZnO Nanoparticles. Nanoscale Research Letters, 10(1), 336. doi:10.1186/s11671-015-1047-4

Han, J.-H., Wang, M. S., Das, J., Sudheendra, L., Vonasek, E., Nitin, N., \& Kennedy, I. M. (2014). Capture and detection of T7 bacteriophages on a nanostructured interface. ACS Applied Materials \& Interfaces, 6(7), 4758-4765. doi:10.1021/am500655r

Handojo, A., Lee, J., Hipp, J., \& Pascall, M. A. (2009). Efficacy of Electrolyzed Water and an Acidic Formulation Compared with Regularly Used Chemical Sanitizers for Tableware Sanitization during Mechanical and Manual Ware-Washing Protocols. Journal of Food Protection, 6, 1315-1320.

He, W., Zhao, H., Jia, H., Yin, J.-J., \& Zheng, Z. (2014). Determination of reactive oxygen species from $\mathrm{ZnO}$ micro-nano structures with shape-dependent photocatalytic activity. Materials Research Bulletin, 53, 246-250. doi:10.1016/j.materresbull.2014.02.020

Heinlaan, M., Ivask, A., Blinova, I., Dubourguier, H. C., \& Kahru, A. (2008). Toxicity of nanosized and bulk $\mathrm{ZnO}, \mathrm{CuO}$ and $\mathrm{TiO} 2$ to bacteria Vibrio fischeri and crustaceans Daphnia magna and Thamnocephalus platyurus. Chemosphere, 71(7), 1308-1316. doi:10.1016/j.chemosphere.2007.11.047

Hoerter, J. D., Arnold, A. a, Kuczynska, D. a, Shibuya, A., Ward, C. S., Sauer, M. G., Johnson, S. (2005). Effects of sublethal UVA irradiation on activity levels of oxidative defense enzymes and protein oxidation in Escherichia coli. Journal of Photochemistry and Photobiology. B, Biology, 81(3), 171-80. doi:10.1016/j.jphotobiol.2005.07.005 
Hotze, E. M., Badireddy, A. R., Chellam, S., Wiesner, M. R. (2009). Mechanisms of Bacteriophage Inactivation via Singlet Oxygen Generation in UV Illuminated Fullerol Suspensions. Environmental Science and Technology, 43(17), 6639-6645.

Huang, Z., Zheng, X., Yan, D., Yin, G., Liao, X., Kang, Y., Hao, B. (2008). Toxicological effect of $\mathrm{ZnO}$ nanoparticles based on bacteria. Langmuir : The ACS Journal of Surfaces and Colloids, 24(8), 4140-4144. doi:10.1021/la7035949

Jin, T., Sun, D., Su, J. Y., Zhang, H., \& Sue, H.-J. (2009). Antimicrobial efficacy of zinc oxide quantum dots against Listeria monocytogenes, Salmonella Enteritidis, and Escherichia coli O157:H7. Journal of Food Science, 74(1), M46-M52. doi:10.1111/j.1750-3841.2008.01013.x

Jones, N., Ray, B., Ranjit, K. T., \& Manna, A. C. (2008). Antibacterial activity of ZnO nanoparticle suspensions on a broad spectrum of microorganisms. FEMS Microbiology Letters, 279(1), 71-76. doi:10.1111/j.1574-6968.2007.01012.x

Kairyte, K., Kadys, A., \& Luksiene, Z. (2013). Antibacterial and antifungal activity of photoactivated $\mathrm{ZnO}$ nanoparticles in suspension. Journal of Photochemistry and Photobiology. B, Biology, 128, 78-84. doi:10.1016/j.jphotobiol.2013.07.017

Karunakaran, C., Rajeswari, V., \& Gomathisankar, P. (2011). Enhanced photocatalytic and antibacterial activities of sol-gel synthesized $\mathrm{ZnO}$ and $\mathrm{Ag}-\mathrm{ZnO}$. Materials Science in Semiconductor Processing, 14(2), 133-138. doi:10.1016/j.mssp.2011.01.017

Kondo, N., Murata, M., \& Isshiki, K. (2006). Efficiency of Sodium Hypochlorite, Fumaric Acid, and Mild Heat in Killing Native Microflora and Escherichia coli O157:H7, Salmonella Typhimurium DT104, and Staphylococcus aureus Attached to Fresh-Cut Lettuce. Journal of Food Protection, 2, 323-329.

Le, P., Zhang, L., Lim, V., McCarthy, M. J., \& Nitin, N. (2015). A novel approach for measuringresistance of Escherichia coli and Listeria monocytogenes to hydrogen peroxide using label-free magnetic resonance imaging and relaxometry. Food Control, 50, 560-567. doi:10.1016/j.foodcont.2014.09.038

Leung, Y. H., Chan, C. M. N., Ng, a M. C., Chan, H. T., Chiang, M. W. L., Djurišić, a B., Au, D. T. W. (2012). Antibacterial activity of $\mathrm{ZnO}$ nanoparticles with a modified surface under ambient illumination. Nanotechnology, 23(47), 475703. doi:10.1088/0957$4484 / 23 / 47 / 475703$

Li, D., \& Haneda, H. (2003). Morphologies of zinc oxide particles and their effects on photocatalysis. Chemosphere, 51(2), 129-137. doi:10.1016/S0045-6535(02)00787-7

Lipovsky, A., Gedanken, A., Nitzan, Y., \& Lubart, R. (2011). Enhanced inactivation of bacteria by metal-oxide nanoparticles combined with visible light irradiation. Lasers in Surgery and Medicine, 43(3), 236-240. doi:10.1002/lsm.21033

Liu, H.-L., \& Yang, T. C.-K. (2003). Photocatalytic inactivation of Escherichia coli and Lactobacillus helveticus by $\mathrm{ZnO}$ and $\mathrm{TiO} 2$ activated with ultraviolet light. Process Biochemistry, 39(4), 475-481. doi:10.1016/S0032-9592(03)00084-0 
Luksiene, Z., \& Brovko, L. (2013). Antibacterial Photosensitization-Based Treatment for Food Safety. Food Engineering Reviews, 5(4), 185-199. doi:10.1007/s12393-013-90707

Maiti, S., Krishnan, D., Barman, G., Ghosh, S., \& Laha, J. (2014). Antimicrobial activities of silver nanoparticles synthesized from Lycopersicon esculentum extract. Journal of Analytical Science and Technology, 5(1), 40. doi:10.1186/s40543-014-0040-3

Miki, T., \& Hardt, W.-D. (2013). Outer membrane permeabilization is an essential step in the killing of gram-negative bacteria by the lectin RegIII $\beta$. PloS One, 8(7), e69901. doi:10.1371/journal.pone.0069901

Mollenhauer, H. H. (1964). Plastic embedding mixtures for use in electron microscopy. Stain Technol, (39), 111-114.

Murakami, L. S., Ferreira, L. P., Santos, J. S., da Silva, R. S., Nomizo, a, Kuz'min, V. a, \& Borissevitch, I. E. (2015). Photocytotoxicity of a cyanine dye with two chromophores toward melanoma and normal cells. Biochimica et Biophysica Acta, 1850(6), 1150-1157. doi:10.1016/j.bbagen.2014.12.005

Ngadi, M., Smith, J. P., \& Cayouette, B. (2003). Kinetics of ultraviolet light inactivation ofEscherichia coli O157:H7 in liquid foods. Journal of the Science of Food and Agriculture, 83(15), 1551-1555. doi:10.1002/jsfa.1577

Omar, G. S., Wilson, M., \& Nair, S. P. (2008). Lethal photosensitization of wound-associated microbes using indocyanine green and near-infrared light. BMC Microbiology, 8, 111. doi:10.1186/1471-2180-8-111

Orlandi, V. T., Caruso, E., Banfi, S., \& Barbieri, P. (2012). Effect of organic matter on the in vitro photoeradication of Pseudomonas aeruginosa by means of a cationic tetraarylporphyrin. Photochemistry and Photobiology, 88(3), 557-564. doi:10.1111/j.17511097.2012.01122.x

Padmavathy, N., \& Vijayaraghavan, R. (2008). Enhanced bioactivity of ZnO nanoparticlesan antimicrobial study. Science and Technology of Advanced Materials, 9(3), 035004. doi:10.1088/1468-6996/9/3/035004

Pigott, D. C. (2008). Foodborne illness. Emergency Medicine Clinics of North America, 26(2), 475-497, x. doi:10.1016/j.emc.2008.01.009

Raghupathi, K. R., Koodali, R. T., \& Manna, A. C. (2011). Size-dependent bacterial growth inhibition and mechanism of antibacterial activity of zinc oxide nanoparticles. Langmuir, 27(7), 4020-4028. doi:10.1021/la104825u

Ramaswamy, R., Ahn, J., Balasubramaniam, V. M., Rodriguez Saona, L., \& Yousef, A. E. (2013). Food Safety Engineering. In Kutz, M. (ed), Handbook of Farm, Dairy and Food Machinery Engineering. Handbook of Farm, Dairy and Food Machinery Engineering (pp.43-66). Academic Press Inc. doi:10.1016/B978-0-12-385881-8.00003-3 
Sawai, J., \& Yoshikawa, T. (2004). Quantitative evaluation of antifungal activity of metallic oxide powders $(\mathrm{MgO}, \mathrm{CaO}$ and $\mathrm{ZnO})$ by an indirect conductimetric assay. Journal of Applied Microbiology, 96(4), 803-809. doi:10.1111/j.1365-2672.2004.02234.x

SCOGS, F. (n.d.). SCOGS (Select Committee on GRAS Substances). Retrieved from http://www.accessdata.fda.gov/scripts/fdcc/?set=SCOGS. Accessed on October 15, 2015

Setsukinai, K., Urano, Y., Kakinuma, K., Majima, H. J., \& Nagano, T. (2003). Development of novel fluorescence probes that can reliably detect reactive oxygen species and distinguish specific species. The Journal of Biological Chemistry, 278(5), 3170-5. doi:10.1074/jbc.M209264200

Snow, S. D., Park, K., \& Kim, J. (2014). Cationic Fullerene Aggregates with Unprecedented Virus Photoinactivation E ffi ciencies in Water. Environmental Science and Technology Letters, 1(6), 290-294. doi: 10.1021/ez5001269

Tardat, B., \& Touati, D. (1991). Two global regulators repress the anaerobic expression of MnSOD in Escherichia coli::Fur (ferric uptake regulation) and Arc (aerobic respiration control). Molecular Microbiology, 5(2), 455-65. DOI: 10.1111/j.13652958.1991.tb02129.x

Tirpanalan, Ö., Zunabovic, M., Domig, K. J., \& Kneifel, W. (2011). Mini review : Antimicrobial strategies in the production of fresh-cut lettuce products. In Mendez-Vilas, A.( Ed). Science against Microbial Pathogens: Communicating Current Research and Technological Advances: Number 3, (pp. 176-188). Formatex Research Center.

Tyrrell, R. M., Moss, S. H., \& Davies, D. J. G. (1972). The variation in photoreactivating enzyme activity as a function of the stage of growth of three K12 strains of Escherichia coli. Mutation Research/Fundamental and Molecular Mechanisms of Mutagenesis, 16(4), 345-352. doi:10.1016/0027-5107(72)90202-3

Van Boekel, M. (2002). On the use of the Weibull model to describe thermal inactivation of microbial vegetative cells. International Journal of Food Microbiology, 74(1-2), 139159. doi:10.1016/S0168-1605(01)00742-5

Xie, J., Li, Y., Zhao, W., Bian, L., \& Wei, Y. (2011). Simple fabrication and photocatalytic activity of $\mathrm{ZnO}$ particles with different morphologies. Powder Technology, 207(1-3), 140-144. doi:10.1016/j.powtec.2010.10.019

Zhang, L., Jiang, Y., Ding, Y., Povey, M., \& York, D. (2006). Investigation into the antibacterial behaviour of suspensions of $\mathrm{ZnO}$ nanoparticles ( $\mathrm{ZnO}$ nanofluids). Journal of Nanoparticle Research, 9(3), 479-489. doi:10.1007/s11051-006-9150-1

Zhang, P., Hong, R. Y., Chen, Q., Feng, W. G., \& Badami, D. (2014). Aluminum-doped zinc oxide powders: synthesis, properties and application. Journal of Materials Science: Materials in Electronics, 25(2), 678-692. doi:10.1007/s10854-013-1630-3

Zhou, J., Xu, N. S., \& Wang, Z. L. (2006). Dissolving Behavior and Stability of ZnO Wires in Biofluids: A Study on Biodegradability and Biocompatibility of $\mathrm{ZnO}$ Nanostructures. Advanced Materials, 18(18), 2432-2435. doi:10.1002/adma.200600200 
Table 1. Parameters for the Weibull and log-linear models that describe the inactivation of $E$. coli BL21 at stationary phase by UV-A treatment in presence of $0,0.1,1$ and $5 \mathrm{mM} \mathrm{ZnO.}$

\begin{tabular}{|c|c|c|c|c|c|c|c|c|}
\hline & \multicolumn{2}{|c|}{$0 \mathrm{mM} \mathrm{ZnO}$} & \multicolumn{2}{|c|}{$0.1 \mathrm{mM} \mathrm{ZnO}$} & \multicolumn{2}{|c|}{$1 \mathrm{mM} \mathrm{ZnO}$} & \multicolumn{2}{|c|}{$5 \mathrm{Mm} \mathrm{ZnO}$} \\
\hline & & Log- & & Log- & & Log- & & Log- \\
\hline & Weibull & linear & Weibull & linear & Weibull & linear & Weibull & linear \\
\hline$\beta$ & 0.60 & - & 0.63 & - & 0.75 & - & 0.78 & - \\
\hline$\alpha$ & 12.00 & - & 12.50 & - & 3.40 & - & 3.00 & - \\
\hline $\mathrm{t}_{\mathrm{R}}$ & 48.19 & - & 46.49 & - & 10.34 & - & 8.74 & - \\
\hline $\mathrm{k}$ & - & 0.019 & - & 0.0195 & - & 0.058 & - & 0.075 \\
\hline
\end{tabular}




\begin{tabular}{lcccccccc} 
RMSE & 0.05 & 0.11 & 0.04 & 0.09 & 0.12 & 0.37 & 0.11 & 0.34 \\
MAE & 0.04 & 0.08 & 0.03 & 0.06 & 0.02 & 0.28 & 0.05 & 0.25 \\
$\mathrm{R}^{2}$ & 0.99 & 0.96 & 0.99 & 0.97 & 0.99 & 0.96 & 0.99 & 0.97 \\
Slope & 0.97 & 0.96 & 1.02 & 1.02 & 1.02 & 1.01 & 1.00 & 1.01 \\
Intercept & 0.02 & 0.10 & 0.01 & 0.08 & 0.02 & 0.26 & 0.05 & 0.26 \\
\hline
\end{tabular}


Table 2. Parameters for the Weibull and log-linear models that describe the inactivation of $E$. coli BL21 at logarithmic phases (A) and stationary phase (B) by UV-A treatment in the presence of $1 \mathrm{mM} \mathrm{ZnO}$ at different concentrations of organic content

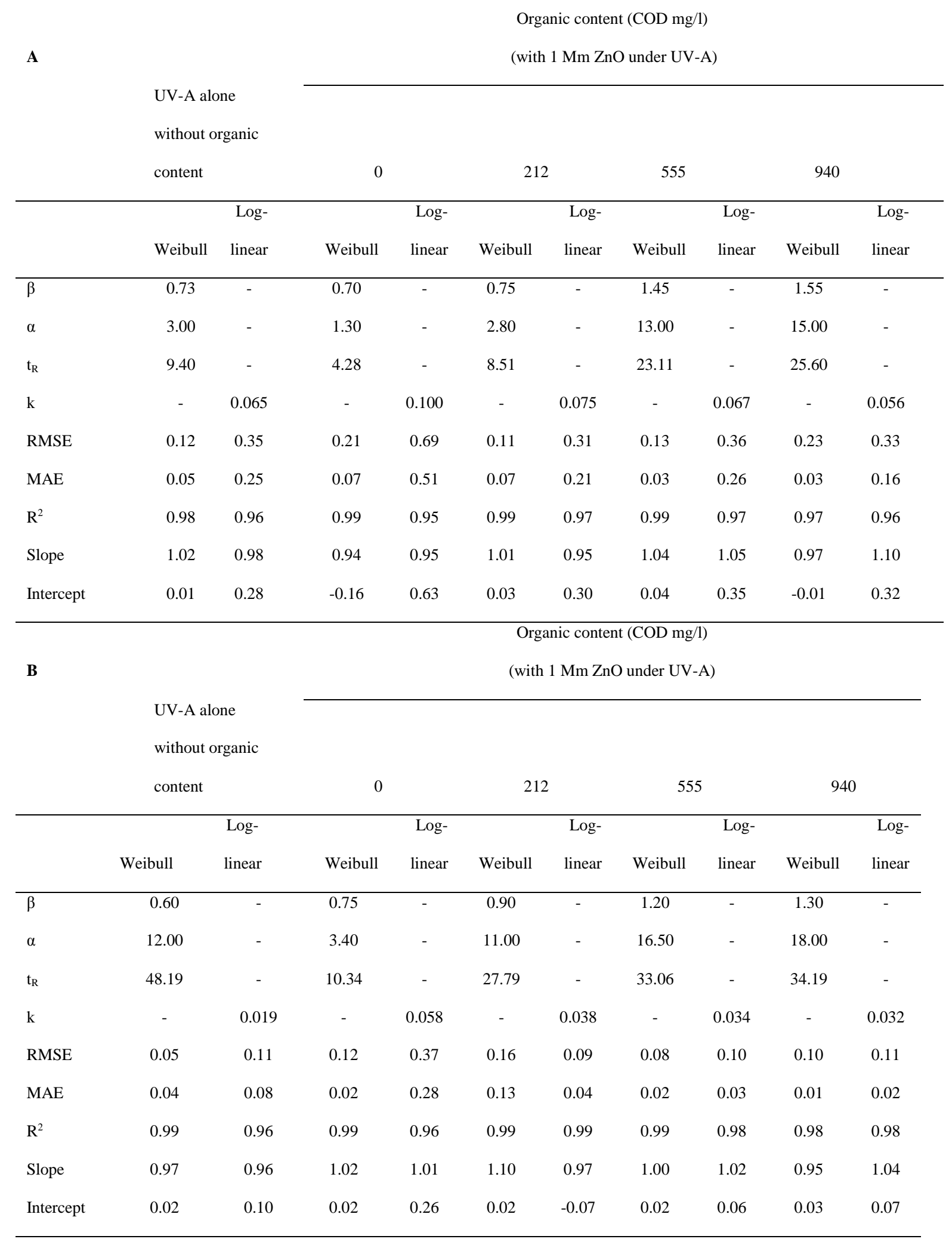


Table 3. Parameters for the Weibull and log-linear models that describe the inactivation of $T 7$ phage by UV-A/ZnO treatment in presence of varying organic load (0-940 $\left.\mathrm{mg} \mathrm{O}_{2} / \mathrm{COD}\right)$

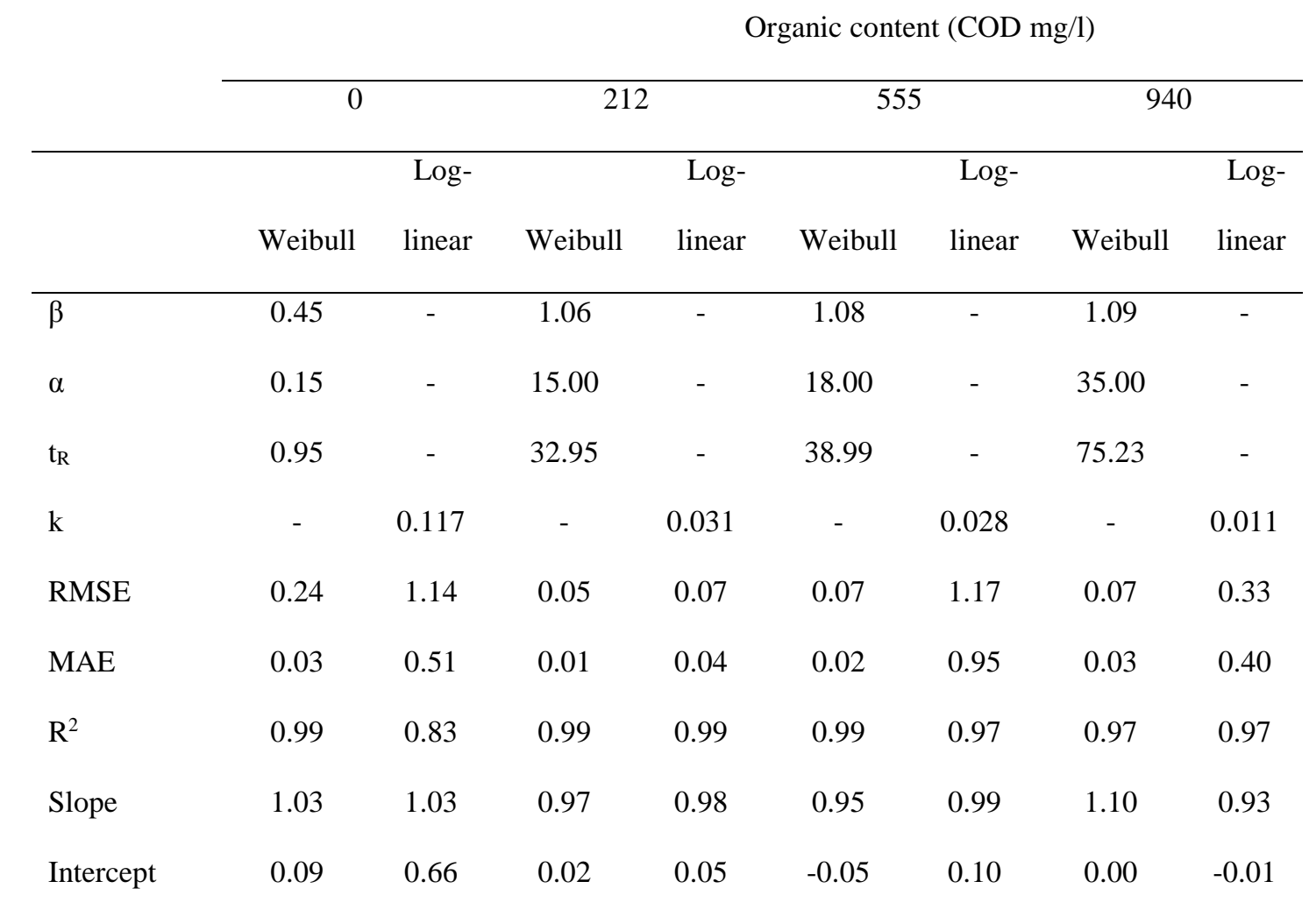




\section{Figure Captions}

Figure 1. A photograph of the bench-top photo-reactor

Figure 2. TEM image of $\mathrm{ZnO}$ particles

Figure 3. The inactivation of E.coli BL21 in the stationary phase as a function of exposure to UV-A light in the presence of 0, 0.1, 1, $5 \mathrm{mM} \mathrm{ZnO}$. (The dots and the line in same color show the experimental values and predicted values by the Weibull model, respectively). Each data point is an average of triplicate measurements \pm standard deviation

Figure 4. The effect of physiological state (logarithmic vs. stationary) of the bacteria on its inactivation rate by UV-A irradiated $1 \mathrm{mM} \mathrm{ZnO}$. (The dots and the line in same color show the experimental values and predicted values by the Weibull model, respectively). Each data point is an average of triplicate measurements \pm standard deviation

Figure 5. The relative fluorescence intensity originating from the binding of SYTOX Orange stain with nucleic acid in the presence or absence of UV-A in (A) stationary and (B) exponential phase bacteria. Each data point is an average of triplicate measurements \pm standard deviation

Figure 6. TEM images of E. coli BL21 at stationary phase before (A) and after treatment with $1 \mathrm{mM} \mathrm{ZnO}$ and UV-A (B) 
Figure 7. The relative fluorescence intensity as a response of $\mathrm{CMH}_{2} \mathrm{DCFDA}(\mathrm{A})$ and HPF (B) probes to the UV-A exposure in the absence and presence of $1 \mathrm{mM} \mathrm{ZnO}$. Each data point is an average of triplicate measurements \pm standard deviation

Figure 8. The effect of UV-A irradiated $1 \mathrm{mM} \mathrm{ZnO}$ at different organic contents on E.coli BL21 at stationary phase (A) and logarithmic phase (B). (The dots and the line in same color show the experimental values and predicted values by the Weibull model, respectively). Each data point is an average of triplicate measurements \pm standard deviation

Figure 9. The effect of UV-A irradiated $1 \mathrm{mM} \mathrm{ZnO}$ at different organic contents on $T 7$ phage (The dots and the line in same color show the experimental values and predicted values by the Weibull model, respectively). Each data point is an average of triplicate measurements \pm standard deviation 


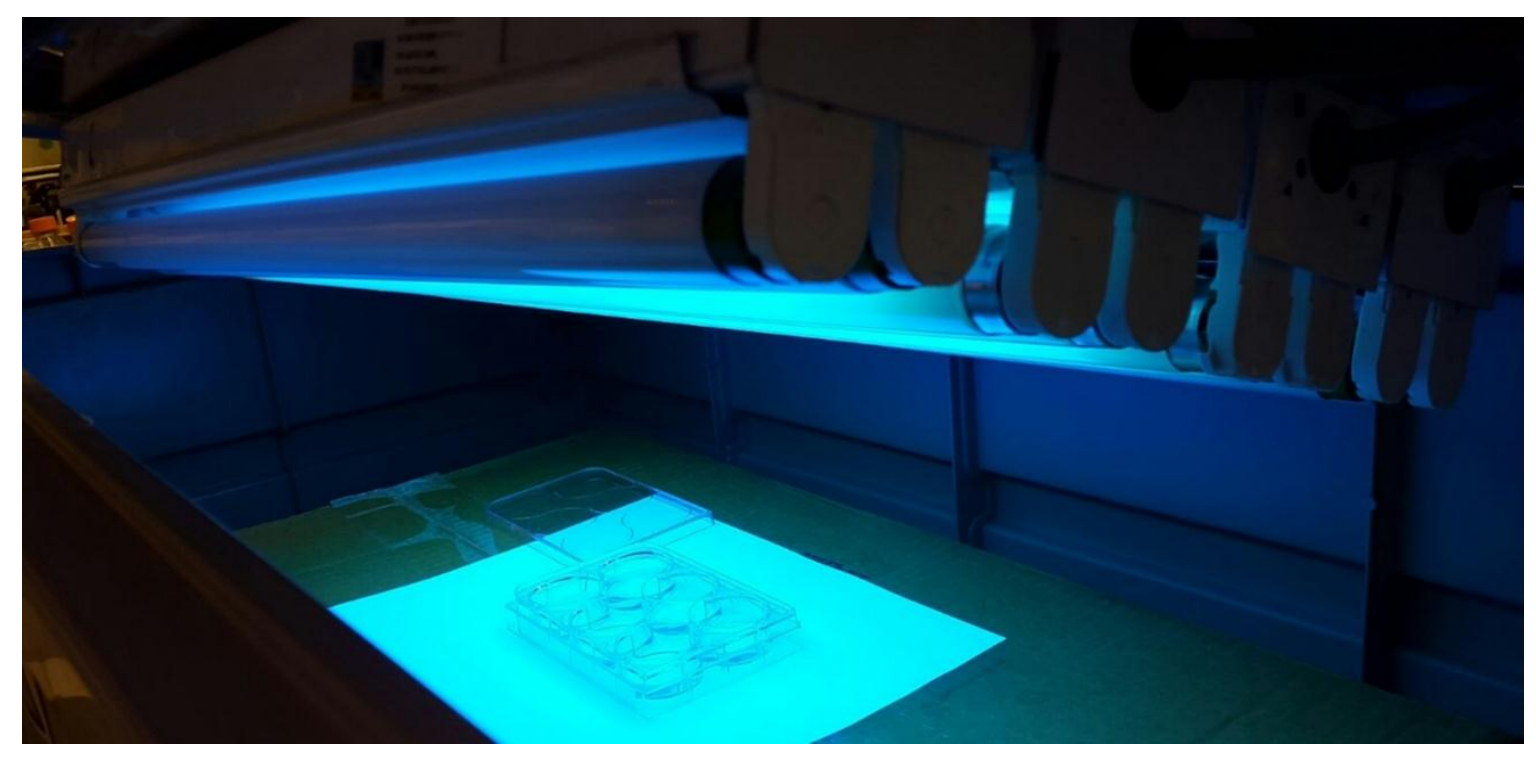




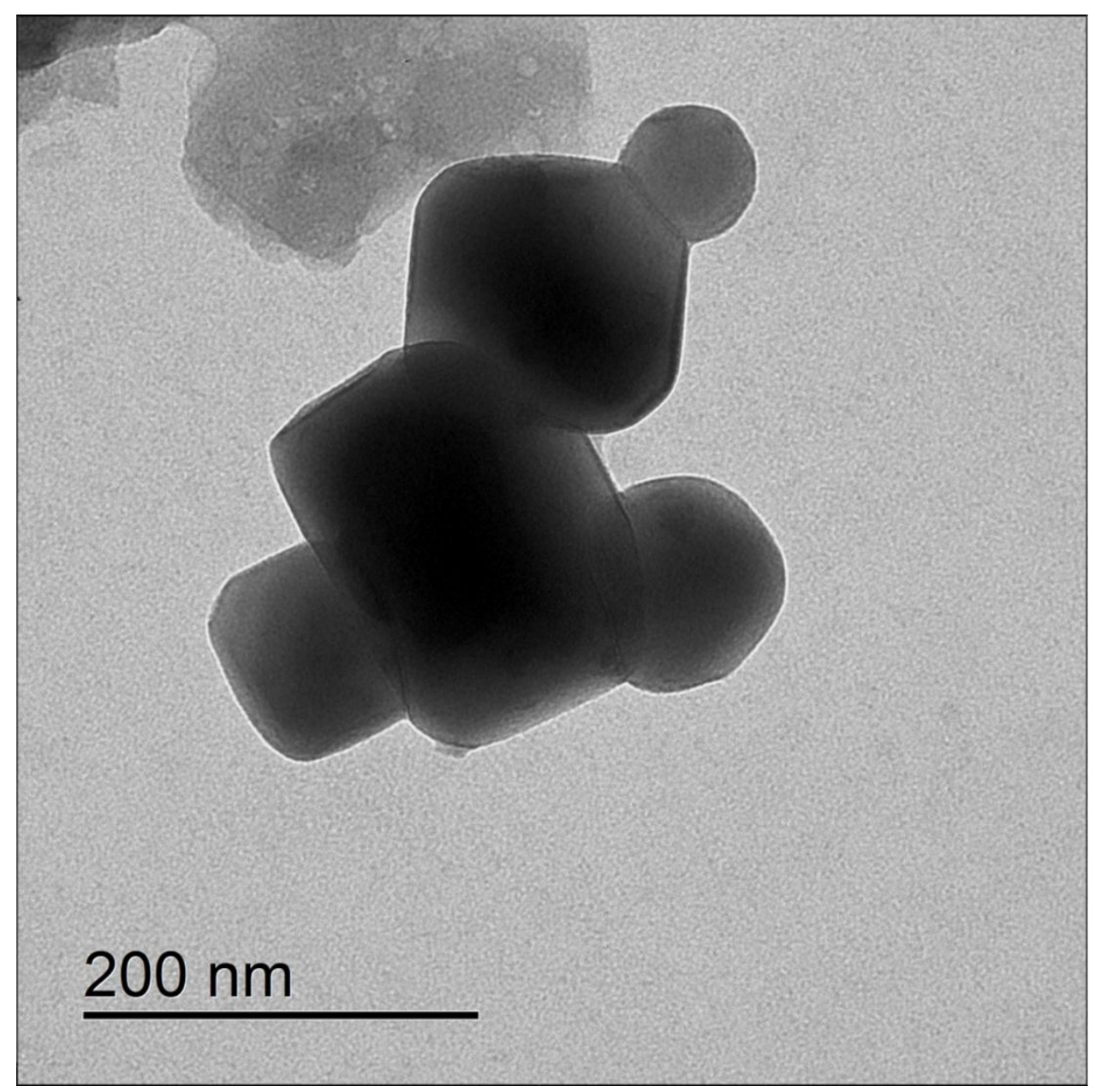




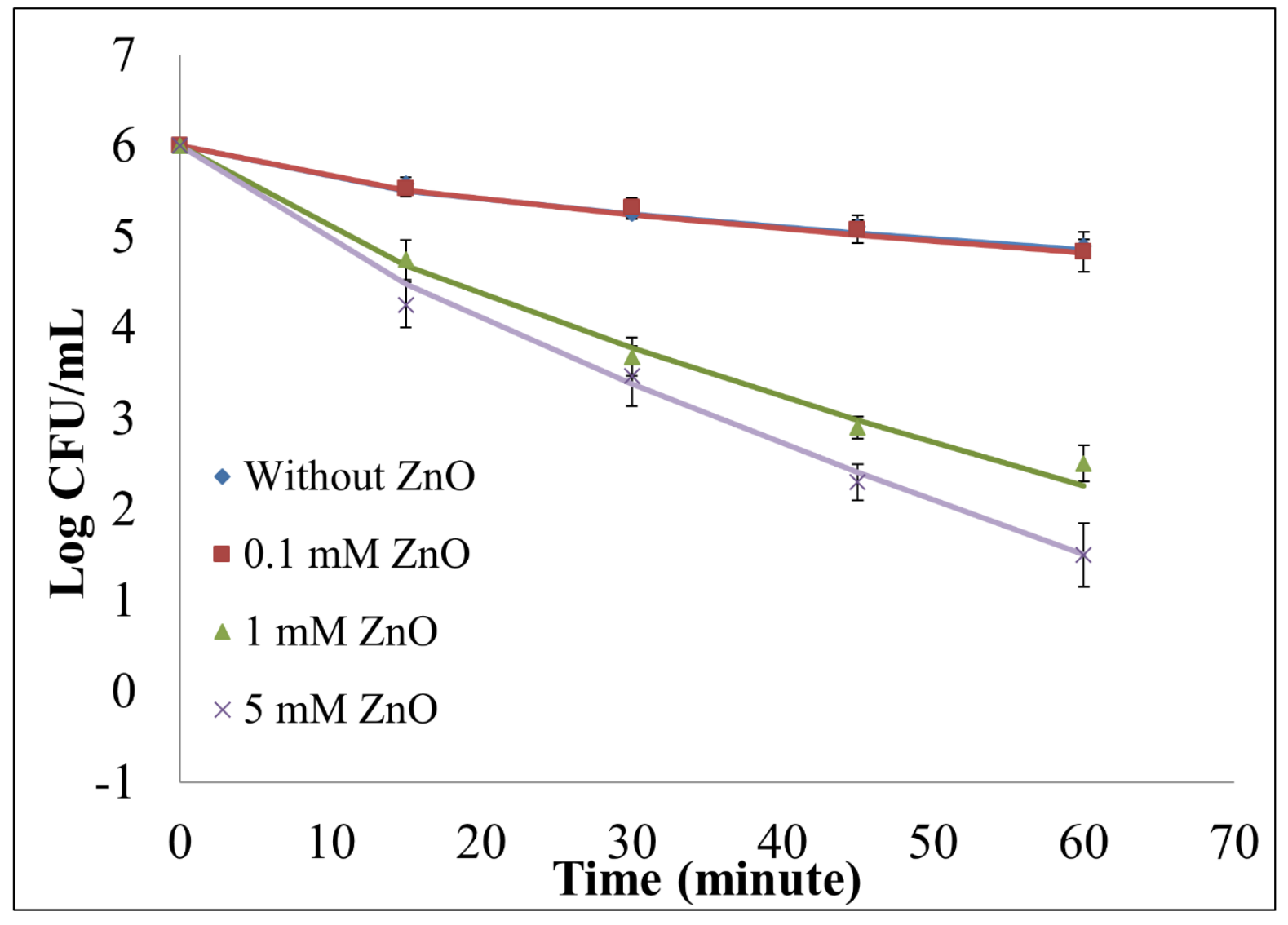




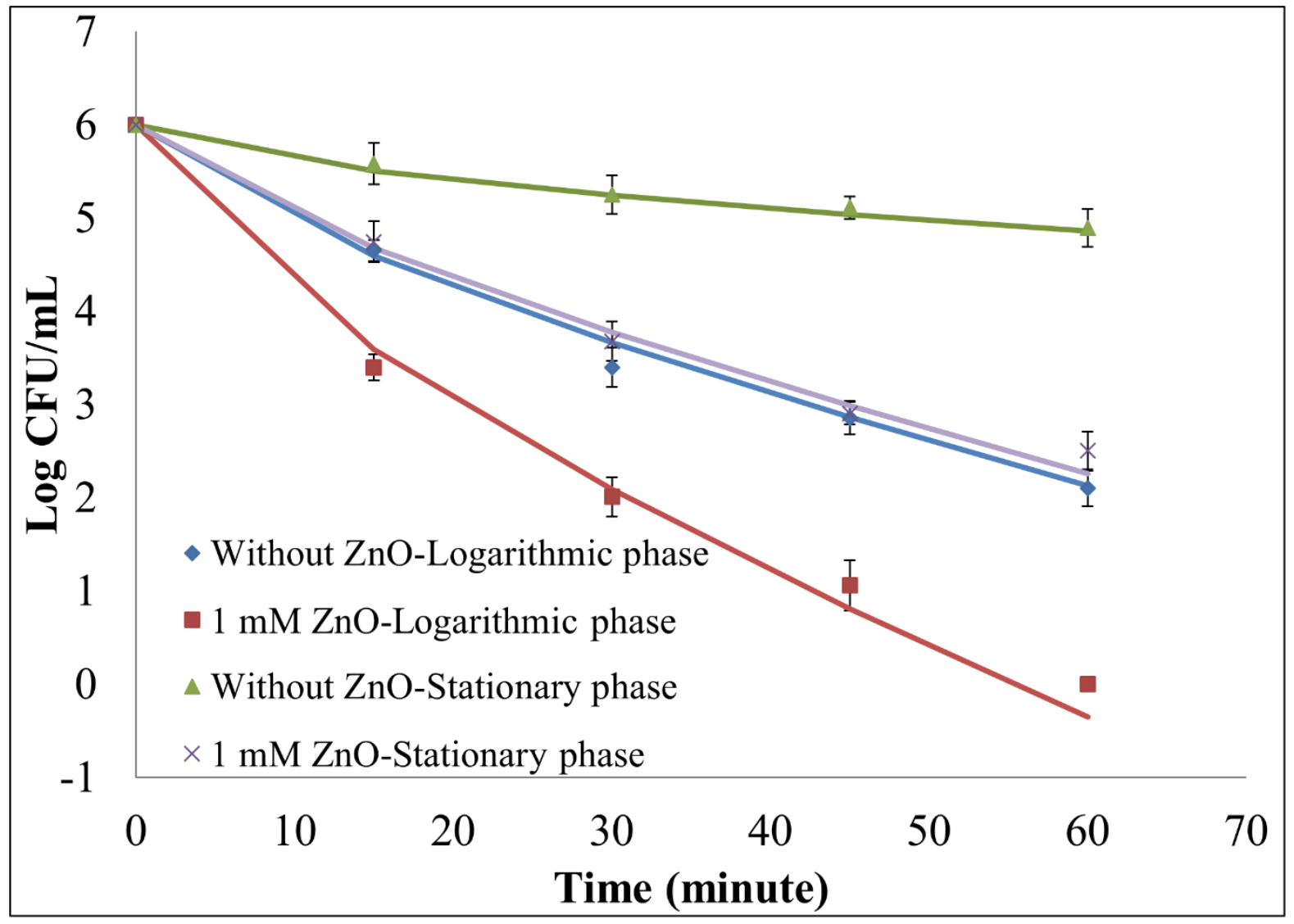




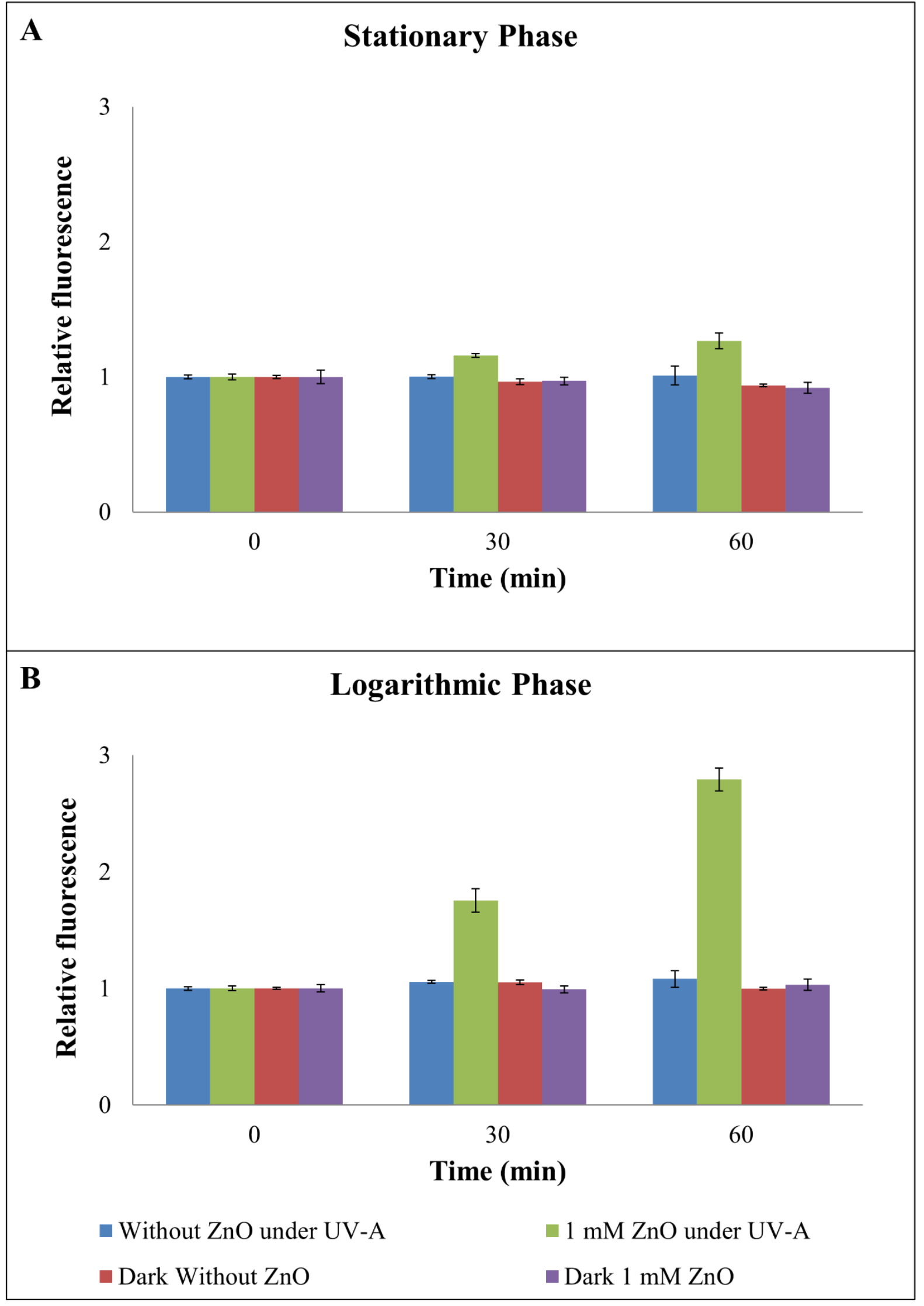




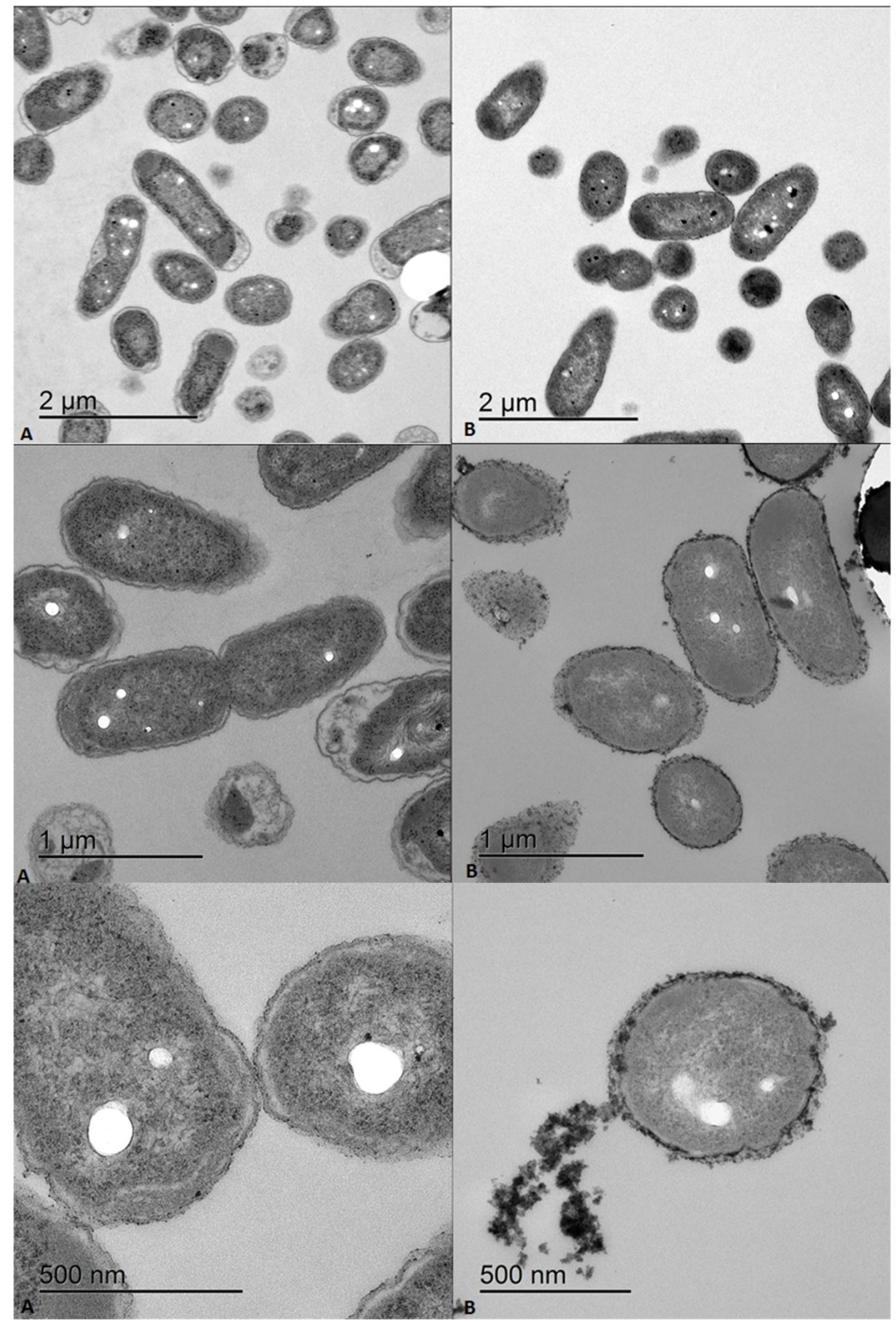




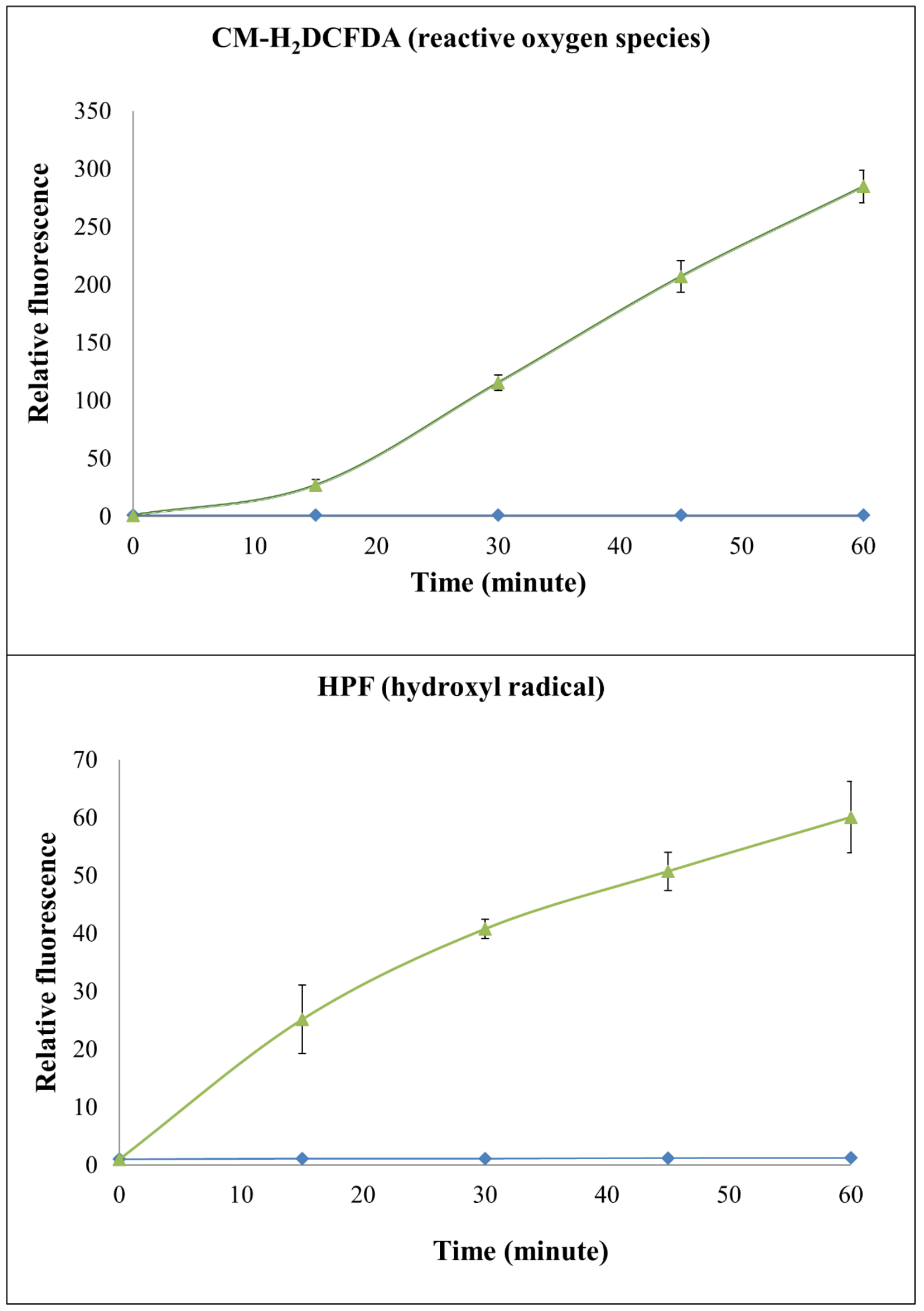




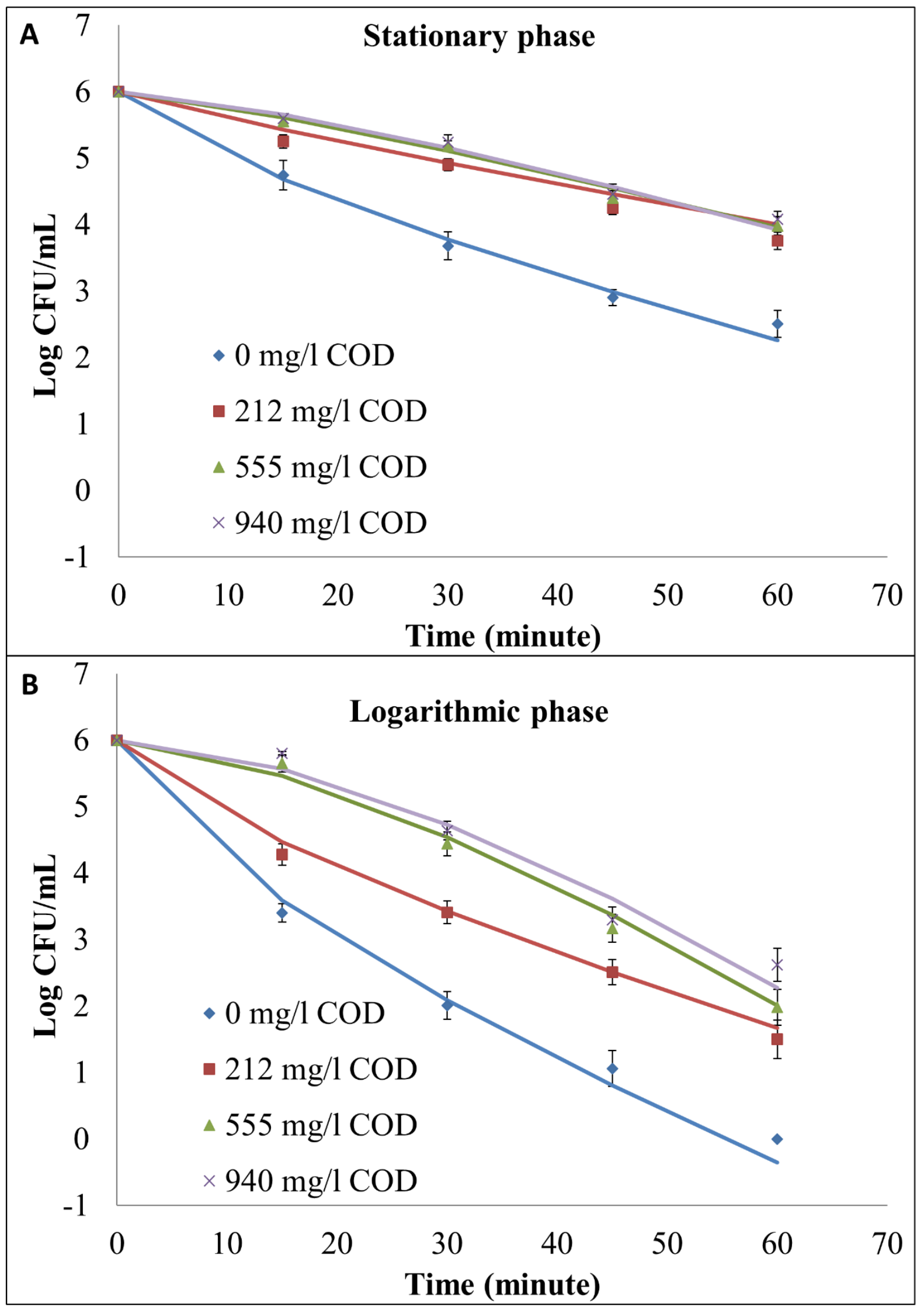




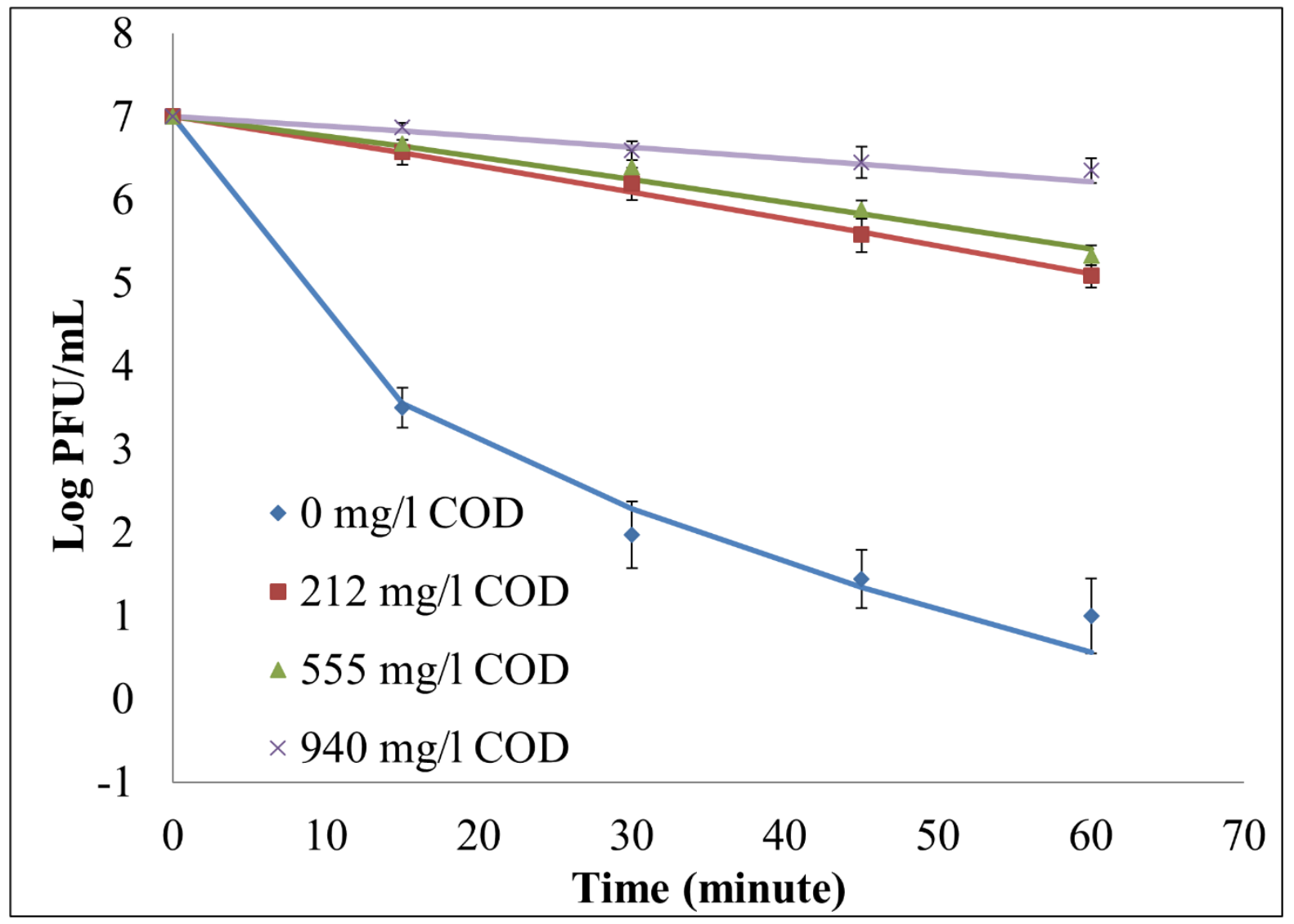

